\title{
Review \\ Non-Musculoskeletal Benefits of Vitamin D beyond the Musculoskeletal System
}

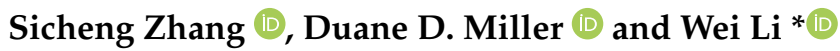 \\ Department of Pharmaceutical Sciences, College of Pharmacy, The University of Tennessee Health Science Center, \\ Memphis, TN 38163, USA; szhang71@uthsc.edu (S.Z.); dmiller@uthsc.edu (D.D.M.) \\ * Correspondence: wli@uthsc.edu; Tel.: +1-901-448-7532
}

Citation: Zhang, S.; Miller, D.D.; Li, W. Non-Musculoskeletal Benefits of Vitamin D beyond the Musculoskeletal System. Int. J. Mol. Sci. 2021, 22, 2128. https:// doi.org/10.3390/ijms22042128

Academic Editors: Andrzej Slominski and Magali Cucchiarini

Received: 28 December 2020

Accepted: 17 February 2021

Published: 21 February 2021

Publisher's Note: MDPI stays neutral with regard to jurisdictional claims in published maps and institutional affiliations.

Copyright: (c) 2021 by the authors. Licensee MDPI, Basel, Switzerland. This article is an open access article distributed under the terms and conditions of the Creative Commons Attribution (CC BY) license (https:/ / creativecommons.org/licenses/by/ $4.0 /)$.

\begin{abstract}
Vitamin D, a fat-soluble prohormone, is endogenously synthesized in response to sunlight or taken from dietary supplements. Since vitamin D receptors are present in most tissues and cells in the body, the mounting understanding of the role of vitamin D in humans indicates that it does not only play an important role in the musculoskeletal system, but has beneficial effects elsewhere as well. This review summarizes the metabolism of vitamin $\mathrm{D}$, the research regarding the possible risk factors leading to vitamin D deficiency, and the relationships between vitamin D deficiency and numerous illnesses, including rickets, osteoporosis and osteomalacia, muscle weakness and falls, autoimmune disorders, infectious diseases, cardiovascular diseases (CVDs), cancers, and neurological disorders. The system-wide effects of vitamin D and the mechanisms of the diseases are also discussed. Although accumulating evidence supports associations of vitamin D deficiency with physical and mental disorders and beneficial effects of vitamin D with health maintenance and disease prevention, there continue to be controversies over the beneficial effects of vitamin D. Thus, more well-designed and statistically powered trials are required to enable the assessment of vitamin D's role in optimizing health and preventing disease.
\end{abstract}

Keywords: vitamin D; musculoskeletal; nonmusculoskeletal; 25-hydroxyvitamin D (25(OH)D); $1 \alpha, 25$-dihydroxyvitamin $\mathrm{D}\left(1 \alpha, 25(\mathrm{OH})_{2} \mathrm{D}\right)$; sunlight

\section{Introduction}

In the mid-17th century, most North-European children who lived in heavily industrialized, polluted cities developed rickets, a severe bone-deforming disease that was characterized by bowed legs, knobby projections of the ribcage, bending of the spine, a large forehead, weak and toneless muscles, and stunted growth. [1-3] Rickets was effectively eradicated in the United States and Europe during the 1930s by the fortification of milk with vitamin D [4]. Vitamin D is a lipid-soluble vitamin, which, however, acts more like a hormone because it can not only be ingested from food and supplements but can also be produced endogenously in humans. The recent interest in vitamin $\mathrm{D}$ has been driven by the mounting recognition of its non-musculoskeletal functions beyond its role in skeletal health, including calcium homeostasis and bone metabolism. Vitamin D deficiency is now recognized as a global health issue that afflicts more than half of the world's population [5,6], and its potential impact on human health is an area of expanding research. In this review, we summarize the factors and consequences of vitamin D deficiency, and the roles of vitamin D in musculoskeletal and non-musculoskeletal health. Despite the positive effects found in cell and murine studies, however, several findings from randomized controlled trials (RCTs) of vitamin D supplementation and nonmusculoskeletal health outcomes are inconsistent, and thus more well-designed and statistically powered trials are required to settle the controversy. 


\section{Biology and Metabolism}

Vitamins $\mathrm{D}_{2}$ (ergocalciferol) and $\mathrm{D}_{3}$ (cholecalciferol) are the two major forms of vitamin D. Vitamin $\mathrm{D}_{3}$ can be obtained directly from animal sources, but it is mainly synthesized by the skin naturally after exposure to ultraviolet (UV) light [7]. The ring-opened compound, previtamin $\mathrm{D}_{3}$, is generated from irradiation of 7-dehydrocholesterol (7-DHC) in the epidermis of the skin, which is followed by thermal isomerization to form vitamin $\mathrm{D}_{3}$. A similar process takes place in fungi, where UV irradiation leads to the formation of vitamin $\mathrm{D}_{2}$ from ergosterol.

\subsection{Classical Pathway of Vitamin D Activation}

Vitamin D that comes from the skin or dietary sources is biologically inert, and two separate hydroxylations are required for full hormonal potency in the human body. The first occurs in the liver and converts vitamin $\mathrm{D}$ to $25(\mathrm{OH}) \mathrm{D}$ or calcidiol by a 25-hydroxylase such as CYP3A4 [8], CYP2R1 [9], CYP2J3 [10], or CYP27A1 [11]. A further hydroxylation occurs primarily in the proximal tubule of the kidney with the aid of mitochondrial $1 \alpha$ hydroxylase (CYP27B1) to give $1 \alpha, 25(\mathrm{OH})_{2} \mathrm{D}$, or calcitriol, the physiologically active form of vitamin D [12]. Vitamin D acts through vitamin D receptor (VDR), a specific nuclear binding receptor which is expressed in most tissues throughout the body. Activation of the VDR by its ligand $1 \alpha, 25(\mathrm{OH})_{2} \mathrm{D}$ leads to attachment of this transcription complex to the respective vitamin D responsive element (VDRE) of the DNA [13]. It was initially thought that the two forms of vitamin $\mathrm{D}$ follow the same metabolic pathway. However, minor differences in the structures of side chains between vitamin $\mathrm{D}_{2}$ and $\mathrm{D}_{3}$ result in differences in the hydroxylation site and lead to the production of unique biologically active metabolites. After a series of oxidations and hydroxylations, both the two forms of vitamin D give rise to calcitroic acid (Figure 1).

\subsection{Non-Classical Pathway of Vitamin D Activation}

Recently, an alternative pathway for vitamin D activation by CYP11A1 has been established. The favored initial hydroxylation occurs at $\mathrm{C} 20$, with $20(\mathrm{OH}) \mathrm{D}$ being the major metabolite [14,15]. Other identified sites of hydroxylation of the vitamin $\mathrm{D}_{3}$ side chain by CYP11A1 are $\mathrm{C} 17, \mathrm{C} 22$, and $\mathrm{C} 23$, and at least 10 metabolites, such as $17(\mathrm{OH}) \mathrm{D}_{3}$, $22(\mathrm{OH}) \mathrm{D}_{3}, 17,20(\mathrm{OH})_{2} \mathrm{D}_{3}, 20,22(\mathrm{OH})_{2} \mathrm{D}_{3}, 20,23(\mathrm{OH})_{2} \mathrm{D}_{3}$, and $17,20,23(\mathrm{OH})_{3} \mathrm{D}_{3}$, are produced $[16,17] .20(\mathrm{OH}) \mathrm{D}_{3}$ and its hydroxymetabolites inhibit DNA synthesis and colony formation, induce cell cycle arrest, and stimulate the differentiation of keratinocytes with a potency comparable to or better than that of $1,25(\mathrm{OH})_{2} \mathrm{D}_{3}$ [18-21]. These hydroxymetabolites also show cell lineage-dependent anti-cancer properties [22-26]. It has been reported that $20(\mathrm{OH}) \mathrm{D}_{3}$ and $20,23(\mathrm{OH})_{2} \mathrm{D}_{3}$ enhance defense mechanisms against UVB-induced oxidative stress and DNA damage in cultured human keratinocytes [27] and murine skin in vivo [28]. As for vitamin $\mathrm{D}_{2}$, in addition to $20(\mathrm{OH}) \mathrm{D}_{2}$, another major product was identified as $17,20(\mathrm{OH})_{2} \mathrm{D}_{2}$, along with some lesser production of $17,20,24(\mathrm{OH})_{3} \mathrm{D}_{2}$ [15]. Studies on $20(\mathrm{OH}) \mathrm{D}_{2}$ have demonstrated that it can also inhibit proliferation and induce the differentiation of keratinocytes [29], and inhibit the proliferation and behavior of normal and malignant melanocytes in a similar manner to $1,25(\mathrm{OH})_{2} \mathrm{D}_{3}$ [30]. Noteworthily, several CYP11A1-derived $\mathrm{D}_{3}$ hydroxymetabolites, such as $20(\mathrm{OH}) \mathrm{D}_{3}, 20(\mathrm{OH}) \mathrm{D}_{2}$, and $20,23(\mathrm{OH})_{2} \mathrm{D}_{3}$, lack toxicities and calcemic effects at very high doses $(3-60 \mu \mathrm{g} / \mathrm{kg})$ in mice, in contrast to $1,25(\mathrm{OH})_{2} \mathrm{D}_{3}$ and $25(\mathrm{OH}) \mathrm{D}_{3}[25,30,31]$.

There has been much debate concerning the relative abilities of vitamin $D_{2}$ and $D_{3}$ to raise vitamin D status. Vitamin $\mathrm{D}_{2}$ was first produced in the early 1920 s, and the process was patented and licensed to pharmaceutical companies, which led to the development of a medicinal preparation of vitamin $\mathrm{D}_{2}$. Pharmacopoeias have officially regarded these two forms as equivalent and interchangeable, yet disagreement exists. Some reports indicate that vitamin $D_{3}$, which has a higher binding affinity to vitamin $\mathrm{D}$ binding protein, is two to three times more effective at increasing blood levels of $25(\mathrm{OH}) \mathrm{D}$ than the equivalent dose of vitamin $\mathrm{D}_{2}$ [32], and several studies suggest that vitamin $\mathrm{D}_{2}$ may indeed have 
a more rapid turnover rate in the serum than vitamin $D_{3}$, though the difference may be inconsequential with daily dosing of vitamin D [33-36]. Although many major prescription forms of vitamin $D$ are actually vitamin $D_{2}$ rather than vitamin $D_{3}$, most companies are now reformulating their products to contain vitamin $\mathrm{D}$ in the $\mathrm{D}_{3}$ form, due to the growing belief that vitamin $D_{3}$ is the better form to be used. However, firm conclusions about any different effects of these two forms of vitamin D cannot be drawn and more research is needed.
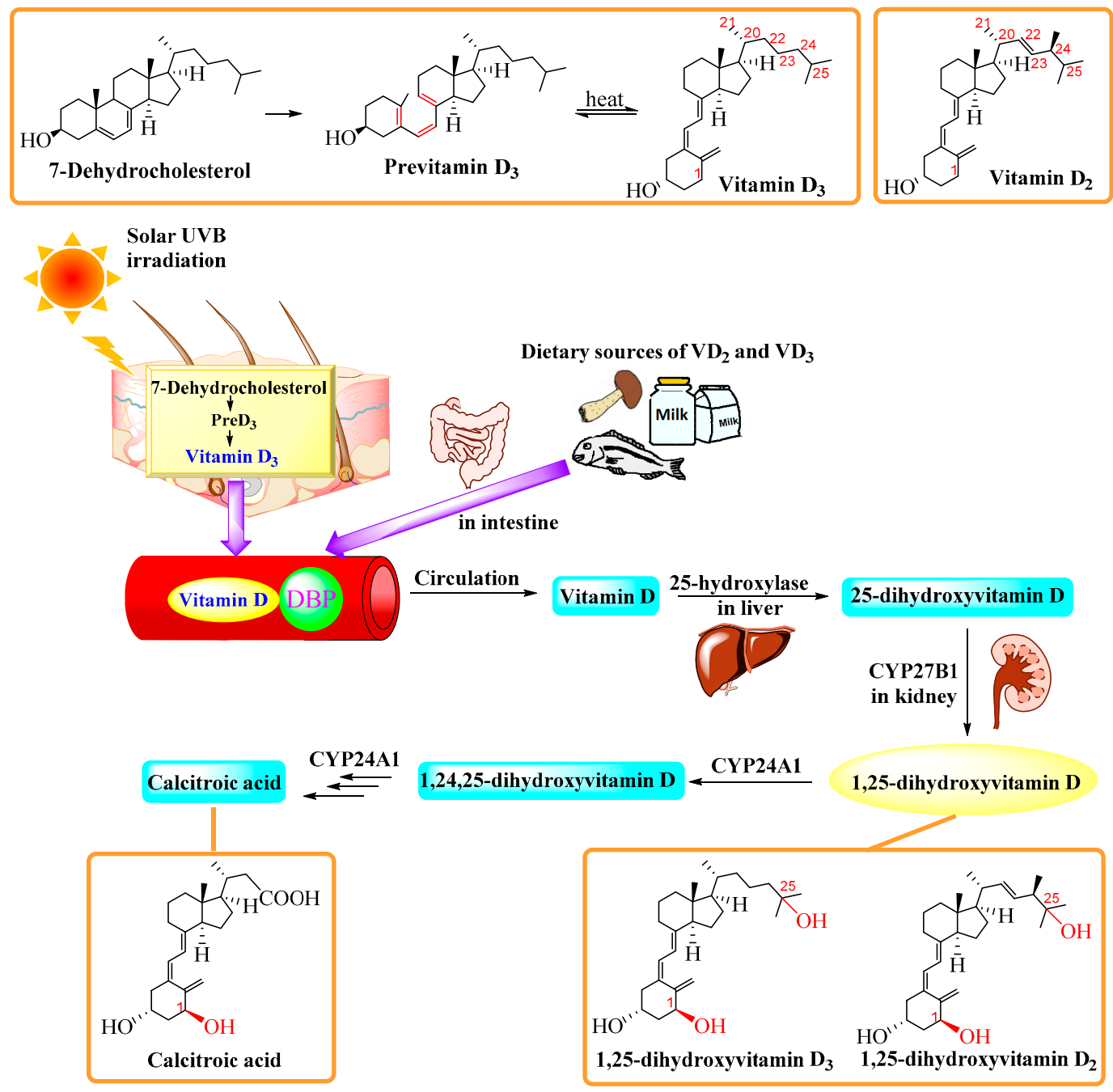

Figure 1. The photoproduction and metabolism of vitamin D. Vitamin $\mathrm{D}_{3}$ is produced in the skin via a two-step process from the vitamin $\mathrm{D}$ substrate 7-DHC, which is converted to previtamin $\mathrm{D}_{3}$ upon exposure to solar ultraviolet $\mathrm{B}$ (UVB) radiation, followed by thermal conversion to vitamin $\mathrm{D}_{3}$. Vitamin $\mathrm{D}_{2}$ and vitamin $\mathrm{D}_{3}$ from dietary sources together with endogenous vitamin $\mathrm{D}_{3}$ are diffused into the circulatory system and bound to vitamin $\mathrm{D}$ binding protein (DBP). Vitamin $\mathrm{D}$ (hereafter " $\mathrm{D}$ " represents $\mathrm{D}_{2}$ or $\mathrm{D}_{3}$ ) is firstly converted by 25-hydroxylase to $25(\mathrm{OH}) \mathrm{D}$ primarily, but not exclusively, in the liver. $25(\mathrm{OH}) \mathrm{D}$ is biologically inactive, and it must be further hydroxylated by $1 \alpha$-hydroxylase (CYP27B1) into the active form $1 \alpha, 25(\mathrm{OH})_{2} \mathrm{D}$ in the kidney or other targeted cells and tissues. This active form can induce the expression of the enzyme 24-hydroxylase (24-OHase) upon completion of the task. The $24-\mathrm{OHAse}$ enhances the catabolism of $1 \alpha, 25(\mathrm{OH})_{2} \mathrm{D}$ into 1,24,25-hydroxyvitamin D, which can then be successively oxidized into the biologically inert calcitroic acid.

\section{Definition of Vitamin D Deficiency}

The definition of vitamin D deficiency in the past by the clinical diagnosis of nutritional rickets has expanded to a definition based on the serum concentration of 25(OH)D. Although the $25(\mathrm{OH}) \mathrm{D}$ metabolite has no physiological function, it is widely used as an 
indicator to determine a person's vitamin D status because it reflects vitamin D supply from dietary exposure and endogenous synthesis, but also because it is the major circulating form of vitamin D with a long half-life (in the circulation) of 2-3 weeks and it is not under tight homeostatic control. In contrast, $1 \alpha, 25(\mathrm{OH})_{2} \mathrm{D}$, as the active form, is not a suitable indicator because it is homeostatically regulated and has a short half-life $(<4 \mathrm{~h})[37-40]$. Measurement of serum 25(OH)D includes automated enzyme-linked immunosorbent assay, radioimmunoassay, automated immunoassays, high performance liquid chromatography (HPLC), and liquid chromatography coupled with tandem mass spectroscopy (LC-MS/MS). Currently, HPLC with MS/MS detection has been established as the gold standard for serum 25(OH)D level testing [41].

There is yet no consensus on optimal serum $25(\mathrm{OH})$ D levels, since different organizations and institutions have their own definitions of vitamin $\mathrm{D}$ status and recommendation for supplementation [42], leading to difficulty in creating an accurate definition of vitamin D deficiency. Despite the controversy, serum levels of 25(OH)D below $20 \mathrm{ng} / \mathrm{mL}$ $(50 \mathrm{nmol} / \mathrm{L})$ should be avoided, since they may cause increases in parathyroid hormone (PTH) [43]. An increase in PTH mediates the mobilization of calcium from bone, resulting in a reduction of bone mass and consequently an increased number of fractures [44].

\section{Factors Leading to Vitamin D Deficiency}

Several factors may contribute to the prevalence of vitamin D deficiency and the resurgence of rickets in our modern society, including variations in sun exposure; age; obesity; and several chronic illnesses, such as kidney, liver, and celiac diseases [45].

\subsection{Exposure to Sunlight}

Vitamin $\mathrm{D}_{3}$ is also called the "sunshine vitamin" because the main source of vitamin $\mathrm{D}_{3}$ for most humans is exposure to sunlight [46,47]. Ultraviolet radiation from the sun is categorized into three types according to wavelength: UVA (315-400 nm), UVB (280$315 \mathrm{~nm})$, and UVC (100-280 nm). For cutaneous vitamin $\mathrm{D}_{3}$ synthesis, the action spectrum for UV-induced conversion of 7-DHC to previtamin $\mathrm{D}_{3}$ in human skin falls within the UVB range [7], indicating a maximum at about $297 \mathrm{~nm}$ with essentially no production above $315 \mathrm{~nm}$. Although recently there have arisen findings casting doubt [48] on the accuracy of this universally recognized action spectrum, it represents a milestone in vitamin $D$ research.

Any barrier that prevents the transmission of solar UVB radiation to the earth's surface or anything that interferes with the penetration of UVB radiation into the skin may significantly reduce vitamin $\mathrm{D}_{3}$ production. For example, a $12.5 \%$ decrease in the atmospheric ozone value from 320 to $280 \mathrm{DU}$ (DU = Dobson unit) at a fixed southern hemisphere site $\left(27.5^{\circ} \mathrm{S}, 151^{\circ} \mathrm{E}\right)$ in clear sky conditions results in an approximate $15 \%$ increase in the monthly amount of vitamin $\mathrm{D}_{3}$-effective UVB radiation that reaches the earth's surface [49]. Additionally, UVB can be absorbed, scattered, or reflected by various additional substances as it travels through the atmosphere, including oxygen and nitrogen, aerosols, water vapor, particulate pollutants, and clouds. For example, thick clouds are found to maintain only $1 \%$ of the surface UVB radiation of clear sky levels [50]. Black carbon particulates from biomass and fossil fuel combustion result in local reductions of UVB radiation by approximately $5 \%$ in typical urban environments [51] and up to $81 \%$ in the rainforests of Brazil [52].

Solar zenith angle (SZA), an angle between the local vertical (zenith) and a line from the observer to the sun, is another key factor influencing UVB radiation. An appropriate SZA is required for UVB to penetrate the non-polluted ozone. In general, the UVB radiation level increases at a smaller SZA and reaches a maximum at mid-day in the summer [53]. UVB radiation can hardly reach the earth's surface at latitudes above $35^{\circ} \mathrm{N}$ and below $35^{\circ} \mathrm{S}$ during the winter months, which produces an almost complete cessation of cutaneous vitamin D synthesis [54]. For example, in Berlin, Germany (latitude $52.5^{\circ} \mathrm{N}$ ) or Amsterdam, Netherlands (latitude $52.4^{\circ} \mathrm{N}$ ), vitamin $\mathrm{D}_{3}$ is not able to be produced between October and April [55]. 


\subsection{Cutaneous Factors}

Prior to triggering vitamin D synthesis from 7-DHC, several factors further attenuate the UVB radiation level. Purdah and cultural coverings limit sunlight exposure and cutaneous vitamin D synthesis, which explains why both children and adults are commonly at high risk of vitamin D deficiency even in the sunniest areas of the world [56]. Melanin in the epidermis of darkly pigmented skin acts as an effective natural sunscreen, which is extremely efficient at absorbing UVB radiation and thus reduces vitamin D synthesis. Compared to individuals with lower concentrations of melanin, those with darkly pigmented skin need longer UV exposure times to generate the equivalent amount of vitamin D [57]. Observational studies [58-60] reported that individuals with higher melanization in the skin have poorer vitamin D status than those with lighter skin at comparable latitude. The explanation for these observations is that the capability of melanin to absorb UVB energy attenuates the final UVB dose reaching epidermal 7-DHC, which thus inhibits the previtamin $\mathrm{D}_{3}$ production [61]. On the other hand, several studies [59,62] showed that skin pigmentation does not influence the synthesis of vitamin D and 25(OH)D. Although it was difficult to integrate the contradictory evidence, a systematic review in 2015 [63] concluded that studies reporting an inhibitory effect of melanin were more convincing than those that observed no influence. However, a very recent study [64] indicated that compared to erythema, melanin offered limited inhibition of vitamin $\mathrm{D}_{3}$ production.

In addition, there are controversies about the association between vitamin D deficiency and sunscreen application. Several experimental studies [65-68] were in line with the expectation that sunscreen use abrogated the vitamin $\mathrm{D}_{3}$ or $25(\mathrm{OH}) \mathrm{D}$ production after exposure to nonsolar UV radiation. In contrast, a holiday study [69] on 79 healthy Polish volunteers (most with Fitzpatrick skin type II and III) showed that considerable production of vitamin D still occurred in the sunscreen-use group (sun protection factor 15, $\geq 2 \mathrm{mg}$ $\mathrm{cm}^{-2}$ ) compared to that of the discretionary sunscreen-use group, suggesting that typical sunscreen use does not cause vitamin D insufficiency in healthy people with lighter skin types [42]. Overall, the risk of vitamin D deficiency resulting from sunscreen use might be lower than the risks resulting from other behaviors, such as staying in the shade and wearing protective clothing, and it is unlikely to be outweighed by the benefits for skin cancer prevention.

Cutaneous vitamin $\mathrm{D}_{3}$ synthesis is also influenced by 7-DHC levels. Post-burn scar tissue only contains as much as $42.5 \%$ of the 7-DHC typically found in normal skin, and burn patients often develop progressive vitamin $\mathrm{D}$ deficiency if they lack supplementation [70]. Advancing age decreases cutaneous 7-DHC as well. A 70-year-old has only $25 \%$ of the 7-DHC that a vicenarian does, and thus has a $75 \%$ reduced capacity to make vitamin $\mathrm{D}$ in the skin [71].

\subsection{Bioavailability of Vitamin D after Oral Ingestion or Cutaneous Synthesis}

\subsubsection{Bioavailability Decrease}

Fat Malabsorption

Vitamin D is lipid soluble; therefore, it requires some dietary fat in the gut for absorption [72]. After being absorbed with long-chain triglycerides in the small intestine, ingested vitamin $\mathrm{D}$ is incorporated into chylomicrons within the enterocytes and then transported through the lymph system into the systemic circulation [73,74]. Any intestinal malabsorption disorder may impair the absorption of vitamin $\mathrm{D}$ due to a decreased ability to absorb lipids. Absorption decreased by $50 \%,>72 \%$, and $>82 \%$ for the oral dose in patients with celiac disease, biliary obstruction absorption, and chronic pancreatitis, respectively. Impaired vitamin $\mathrm{D}$ absorption was positively associated with the steatorrhea in each case. Furthermore, other conditions, such as liver failure, cystic fibrosis, Crohn's disease (CD), and gastric bypass, cause impaired vitamin $\mathrm{D}$ absorption. This disorder can also be found in individuals who take bile acid-binding medications such as cholestyramine and colestipol for hypercholesterolemia [3,72]. 
Obesity

As discussed above, vitamin $\mathrm{D}$ is readily taken up by adipose tissues. Vitamin $\mathrm{D}$ can be stored in these tissues for subsequent release and metabolism in case production is reduced, such as during the winter months [75]. However, there seems to be an inverse correlation between adipose tissue levels and vitamin $\mathrm{D}$ status. Several studies have shown that obese individuals tend to have lower serum levels of vitamin $\mathrm{D}_{3}$ and $25(\mathrm{OH}) \mathrm{D}_{3}$ than those with normal weights [76-78]. Evaluation of serum vitamin $\mathrm{D}_{3}$ levels $24 \mathrm{~h}$ after whole-body irradiation showed that the increase in vitamin $\mathrm{D}_{3}$ was $57 \%$ lower in obese individuals with body mass index (BMI; in $\mathrm{kg} / \mathrm{m}^{2}$ ) $\geq 30$ than age-matched lean control subjects $(\mathrm{BMI} \leq 25)$. The study also found that BMI was inversely associated with peak plasma concentrations of vitamin $\mathrm{D}_{2}$ after intake of oral doses of 50,000 IU (IU = international unit, $1 \mathrm{IU}=0.025$ micrograms) of vitamin $\mathrm{D}_{2}$ [79]. Thus, obesity correlates with vitamin $\mathrm{D}$ deficiency and decreased vitamin $\mathrm{D}$ bioavailability. This is likely secondary to the sequestration of vitamin D into larger body fat compartments [80].

\subsubsection{Increases in the Metabolism of Vitamin D}

Metabolism of $25(\mathrm{OH}) \mathrm{D}$ and $1 \alpha, 25(\mathrm{OH})_{2} \mathrm{D}$ is primarily mediated by two cytochrome P450 enzymes. CYP24A1, which acts as 24-hydroxylase, initiates the breakdown of 25(OH)D and $1 \alpha, 25(\mathrm{OH})_{2} \mathrm{D}$ in the kidney, and to a lesser extent, other tissues, whereas CYP3A4 mediates their metabolism in the liver and small intestine [81]. The combined activity of these two enzymes is an important factor in determining the circulating concentrations of $25(\mathrm{OH}) \mathrm{D}$ and $1 \alpha, 25(\mathrm{OH})_{2} \mathrm{D}$ [82]. Long-term use of certain medications, including anticonvulsants, glucocorticoids, phenobarbital, phenytoin, carbamazepine, rifampicin, and antiretrovirals, causes upregulation of CYP3A4. This enhances the metabolism of $25(\mathrm{OH}) \mathrm{D}$ and $1 \alpha, 25(\mathrm{OH})_{2} \mathrm{D}$ and leads to decreased levels of $25(\mathrm{OH}) \mathrm{D}$ and $1 \alpha, 25(\mathrm{OH})_{2} \mathrm{D}$ [83-85].

\section{Liver Disease}

The liver, which is the site for conversion of vitamin $\mathrm{D}$ to $25(\mathrm{OH}) \mathrm{D}$, plays a critical role in the maintenance of vitamin D status. Hepatobiliary disease is often related to vitamin D deficiency [86]. A decrease in the intestinal availability of bile salts in cholestatic liver disease leads to malabsorption of fat-soluble vitamins such as vitamin D. Data from one study showed that following a single oral dose of $1000 \mathrm{IU} / \mathrm{kg}$, the rise in serum vitamin $\mathrm{D}_{2}$ levels in six children with chronic cholestasis since infancy (mean age 12.1 years) was $98.7 \%$ lower than in controls [87]. The low serum 25(OH)D levels in severe parenchymal liver disease are mainly due to vitamin D malabsorption and reduced capacity for 25hydroxylation. A study of 100 patients with noncholestatic chronic liver disease found serum $25(\mathrm{OH}) \mathrm{D}$ levels $<50 \mathrm{nmol} / \mathrm{L}$ in $86.3 \%$ of cirrhotic patients compared with only $49.0 \%$ of noncirrhotic controls [88]. As the primary carrier protein for vitamin $\mathrm{D}, 25(\mathrm{OH}) \mathrm{D}$, and $1 \alpha, 25(\mathrm{OH})_{2} \mathrm{D}$ in circulation, DBP is also synthesized in the liver. DBP binding prolongs the half-life of vitamin $\mathrm{D}$ and its metabolites and facilitates their uptake by target tissues [89]. Decreased levels of serum DBP were observed in patients who suffered from fulminant hepatic failure or chronic liver diseases. [90].

\section{Kidney Disease}

Within the proximal convoluted tubule cells of the kidney, the majority of circulating $1 \alpha, 25(\mathrm{OH})_{2} \mathrm{D}$ is produced by the enzyme $1 \alpha$-hydroxylase. Accordingly, renal pathology can be a key factor of vitamin D deficiency. Chronic kidney disease, defined by the presence of kidney damage or decreased kidney function for three or more months, affects approximately 20 million adults in the US [91]. Serum $1 \alpha, 25(\mathrm{OH})_{2} \mathrm{D}$ level is positively associated with creatinine clearance in chronic kidney disease [92,93] and glomerular filtration deteriorates with disease progression [94]. Serum $1 \alpha, 25(\mathrm{OH})_{2} \mathrm{D}$ levels are usually undetectable in end-stage renal disease. The activity of $1 \alpha$-hydroxylase in renal glands is regulated by PTH and hypophosphatemia through PTH-induced enzyme synthesis and direct stimulation of enzymatic activity [89]. Impaired kidney function secondary to 
chronic kidney disease results in phosphate retention and later hyperphosphatemia, which is a potent inhibitor of renal $1 \alpha$-hydroxylase activity. Loss of functioning kidney mass also causes decreased levels of this enzyme and a consequent deficiency in circulating $1 \alpha, 25(\mathrm{OH})_{2} \mathrm{D}$ [95]. Moreover, low 25(OH)D levels can be observed in nephrotic-range proteinuria due to direct loss of DBP-bound 25(OH)D in the urine [94].

\section{Impacts of Vitamin D on Musculoskeletal Health \\ 5.1. Vitamin D and Bones}

The major role of vitamin $\mathrm{D}$ is to provide and maintain adequate calcium and phosphorus in the body to facilitate optimal metabolic function (Figure 2). Patients suffering from vitamin D deficiency absorb only $10-15 \%$ of dietary calcium and $50-60 \%$ of dietary phosphorus. When one has sufficient vitamin $\mathrm{D}$, calcium and phosphorus absorption can increase $30-40 \%$ and $80 \%$, respectively [5]. As the biologically active form, $1 \alpha, 25(\mathrm{OH})_{2} \mathrm{D}$ accomplishes calcium homeostasis by interacting with VDR in the small intestinal cells, followed by complexing with retinoic acid $X$ receptor (RXR) in the nucleus [96]. The resulting $1 \alpha, 25(\mathrm{OH})_{2} \mathrm{D}-\mathrm{VDR}-\mathrm{RXR}$ complex together with co-regulatory proteins binds to the VDRE for the epithelial calcium channel [97]. The increased expression of the calcium channel permits more calcium to enter the cell, where the vitamin D-dependent calcium-binding protein calbindin- $\mathrm{D}_{9 \mathrm{~K}}$ helps calcium's translocation into the bloodstream. $1 \alpha, 25(\mathrm{OH})_{2} \mathrm{D}$ also enhances calcium and phosphorus absorption in the small intestine and calcium reabsorption in the kidney [3]. The decreased serum-ionized calcium level is immediately recognized by the calcium sensor in the parathyroid glands, resulting in an increase in the expression, synthesis, and secretion of PTH [98-100]. PTH can decrease phosphorus reabsorption in the kidney, causing loss of phosphorus in the urine. The $1 \alpha, 25(\mathrm{OH})_{2} \mathrm{D}$-occupied VDR, together with PTH, enhances the expression of the plasma membrane protein receptor activator of nuclear factor- $\mathrm{KB}$ ligand (RANKL) on osteoblasts to increase the production of mature osteoclasts [98,101]. The mature osteoclasts mobilize calcium and phosphorus from the bone into the circulation via secretion of hydrochloric acid and collagenases. Thus, the major function of vitamin $D$ is to maintain serum levels of calcium and phosphorus within the normal physiological range to support most metabolic functions, bone mineralization, and neuromuscular transmission $[38,98]$.

\subsection{Rickets}

Among infants and young children, vitamin D deficiency is a common cause of bone deformities classically known as rickets [102]. Infants have a relatively high need of vitamin $\mathrm{D}$ because of their high rate of skeletal growth. In the first 4 months of life, an infant's diet consists almost entirely of breastmilk and/or infant formula [103]. Despite the many benefits of breastmilk, the vitamin $\mathrm{D}$ content of breast milk is relatively low and ranges from 25 to $124 \mathrm{IU} / \mathrm{L}[104,105]$. It has been hypothesized [106] that higher calcium or vitamin D supplementation to lactating mothers may result in increased calcium or vitamin $\mathrm{D}$ in the supply from the mother to the infant. However, neither calcium nor vitamin D intake affects the breastmilk calcium levels according to Basile et al. [107]. In other studies, it seemed that maternal vitamin $\mathrm{D}$ status had a great role in the milk vitamin D supply. Several RCTs have assessed the efficacy of the practice, using both regular and bolus dosing regimens (dose range 250-4000 IU / day or equivalent), and have observed it to raise both infant and maternal vitamin D status $[96,106,108,109]$. However, the follow-up period of these studies only extended to 7 months of age at the most [106]. Longer RCTs are required to assess the long-term benefit in future studies. In order to maintain safe vitamin D status, a daily supplement of $400 \mathrm{IU}$ of vitamin $\mathrm{D}_{3}$ for breast-fed infants, as recommended by the Institute of Medicine of US, should be practiced [110]. 


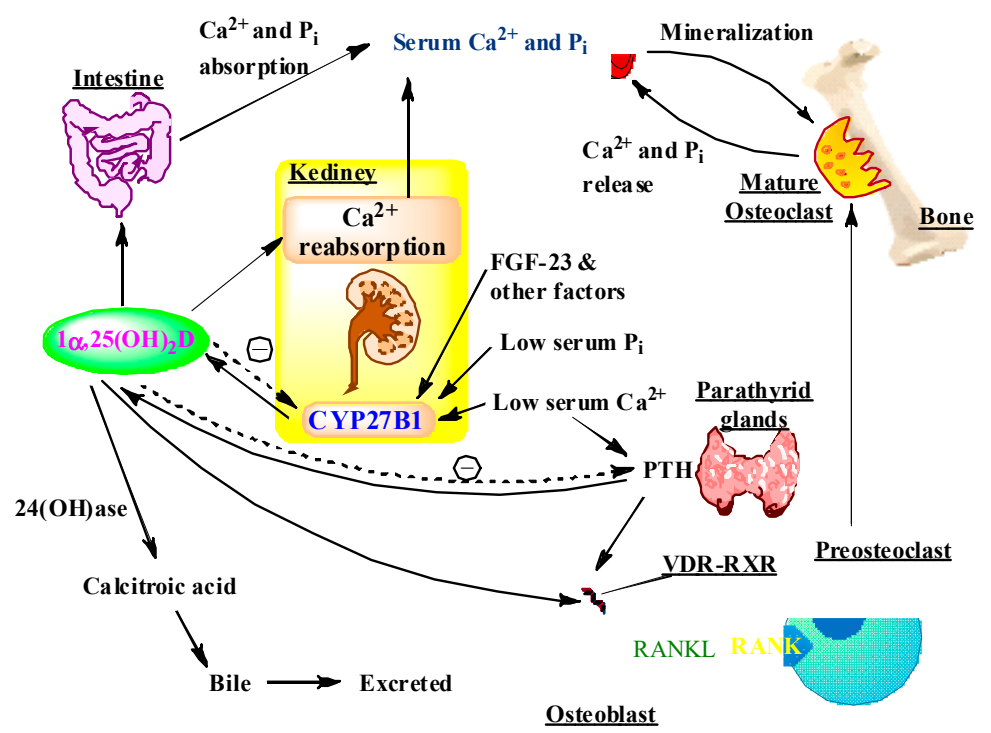

Figure 2. The effects of $1 \alpha, 25(\mathrm{OH})_{2} \mathrm{D}$ on calcium and phosphorus homeostasis. $1 \alpha, 25(\mathrm{OH})_{2} \mathrm{D}$ is produced by the kidney under the control of PTH by the parathyroid glands. PTH stimulates its production and $1 \alpha, 25(\mathrm{OH})_{2} \mathrm{D}$ in turn inhibits the synthesis and secretion of PTH. $1 \alpha, 25(\mathrm{OH})_{2} \mathrm{D}$ can also decrease its own synthesis through negative feedback. $1 \alpha, 25(\mathrm{OH})_{2} \mathrm{D}$ enhances intestinal calcium and phosphorus absorption in the small intestine and calcium reabsorption in the kidney. $1 \alpha, 25(\mathrm{OH})_{2} \mathrm{D}$ regulates bone formation and resorption by stimulation of preosteoblast proliferation and differentiation into osteoblasts. $1 \alpha, 25(\mathrm{OH})_{2} \mathrm{D}$ also stimulates the expression of RANKL by osteoblasts, which stimulates the differentiation and subsequent activation of preosteoclasts into mature osteoclasts, the bone-forming cells which release calcium $\left(\mathrm{Ca}^{2+}\right)$ and inorganic phosphorus (Pi) from the bone to maintain calcium and phosphorus levels in the blood. Adequate calcium and phosphorus levels promote the mineralization of the skeleton. $1 \alpha, 25(\mathrm{OH})_{2} \mathrm{D}$ stimulates the expression of the renal 24-hydroxylase (24-OHase) to catabolize $1 \alpha, 25(\mathrm{OH})_{2} \mathrm{D}$ to the water-soluble, biologically inactive calcitroic acid, which is excreted in the bile. Other factors, such as serum phosphorus, calcium, and fibroblast growth factor 23 can either increase or decrease the renal production of $1 \alpha, 25(\mathrm{OH})_{2} \mathrm{D}$.

\subsection{Osteoporosis and Osteomalacia}

Vitamin D deficiency also precipitates and exacerbates osteoporosis among adults and causes the painful bone disease called osteomalacia. Osteoporosis is a systemic skeletal disease characterized by decreased bone strength and increased risk of fractures. Although rickets is rare in the United States, osteoporosis affects one in three women and one in twelve men. Fractures of the wrist, hip, and vertebrae are the three main manifestations of osteoporosis and in at-risk populations cause excess mortality, a considerable economic burden, and a decrease in quality of life [111]. The risk of developing an osteoporotic fracture increases with advancing age. As a result, in the elderly, vitamin D levels have been suggested to be the best predictor of fracture risk [112]. In a study of more than 500 individuals with hip fractures, 95\% were found to be vitamin D deficient [113]. A study of 82 patients with minimal trauma fracture found that all except two individuals had vitamin D levels less than $30 \mathrm{ng} / \mathrm{mL}$ [114]. Vitamin D trials have suggested that achievement of vitamin D sufficiency could reduce common osteoporotic fractures by 50 to $60 \%$ [115].

In addition to vitamin $\mathrm{D}$ deficiency, age, and gender, risk factors for osteoporotic fractures include Asian or Caucasian ethnic origin, low body weight, low dietary calcium intake, cigarette smoking, excessive alcohol consumption, long-term immobilization, low estrogen levels, glucocorticoid therapy, and low bone mineral density [116]. As serum $25(\mathrm{OH}) \mathrm{D}$ levels decrease with age, increased supplementation is necessary for most older individuals [117]. A randomized trial demonstrated that the probabilities of hip fractures 
and nonvertebral fractures among elderly women (78 to 90 years of age) who received $800 \mathrm{IU}$ of vitamin $\mathrm{D}_{3}$ daily for 18 months were $43 \%$ and $32 \%$, respectively, lower than among those who received placebo [118].

\subsection{Muscle Weakness and Falls}

Proximal muscle weakness is a prominent clinical feature of vitamin D deficiency. In addition, vitamin $\mathrm{D}$ deficiency is believed to be one of many factors contributing to the development of sarcopenia, the degenerative loss of muscle with aging, and may be an independent risk factor for postural sway and falls $[119,120]$. Falls resulting from neuromuscular dysfunction are the largest single cause of injury-related deaths in elderly people and lead to $40 \%$ of all nursing home admissions [121].

VDRs are located on the fast-twitch muscle fibers, which are the first to be recruited to prevent a fall [122]. It is theorized that $1 \alpha, 25(\mathrm{OH})_{2} \mathrm{D}$ can bind to its receptor in muscle tissues, allowing protein synthesis and muscle cell growth, so that vitamin D can improve muscle strength and function, thereby preventing falls [123,124]. Furthermore, vitamin D may improve neuromuscular function and postural and dynamic balance, leading to a considerable increase in reaction time, and consequently, less falls and fractures [121,124]. A systematic review revealed that supplemental vitamin D given in daily doses of 800 to 1000 IU consistently had beneficial effects on muscle strength and balance [125]. Several RCTs have also reported positive effects of vitamin D supplementation on muscle function and fall prevention [126-128].

\section{Impact of Vitamin D on Non-Musculoskeletal Health}

The existence of VDR in most tissues and cells in the body [129] results in a broad range of biological actions of $1 \alpha, 25(\mathrm{OH})_{2} \mathrm{D}$ (Figure 3 ) in addition to regulating calcium and phosphorus homeostasis. The local production of $1 \alpha, 25(\mathrm{OH})_{2} \mathrm{D}$ may be responsible for regulating up to 200 genes [130] that may facilitate many of the pleiotropic health benefits that have been reported for vitamin D [129,131].

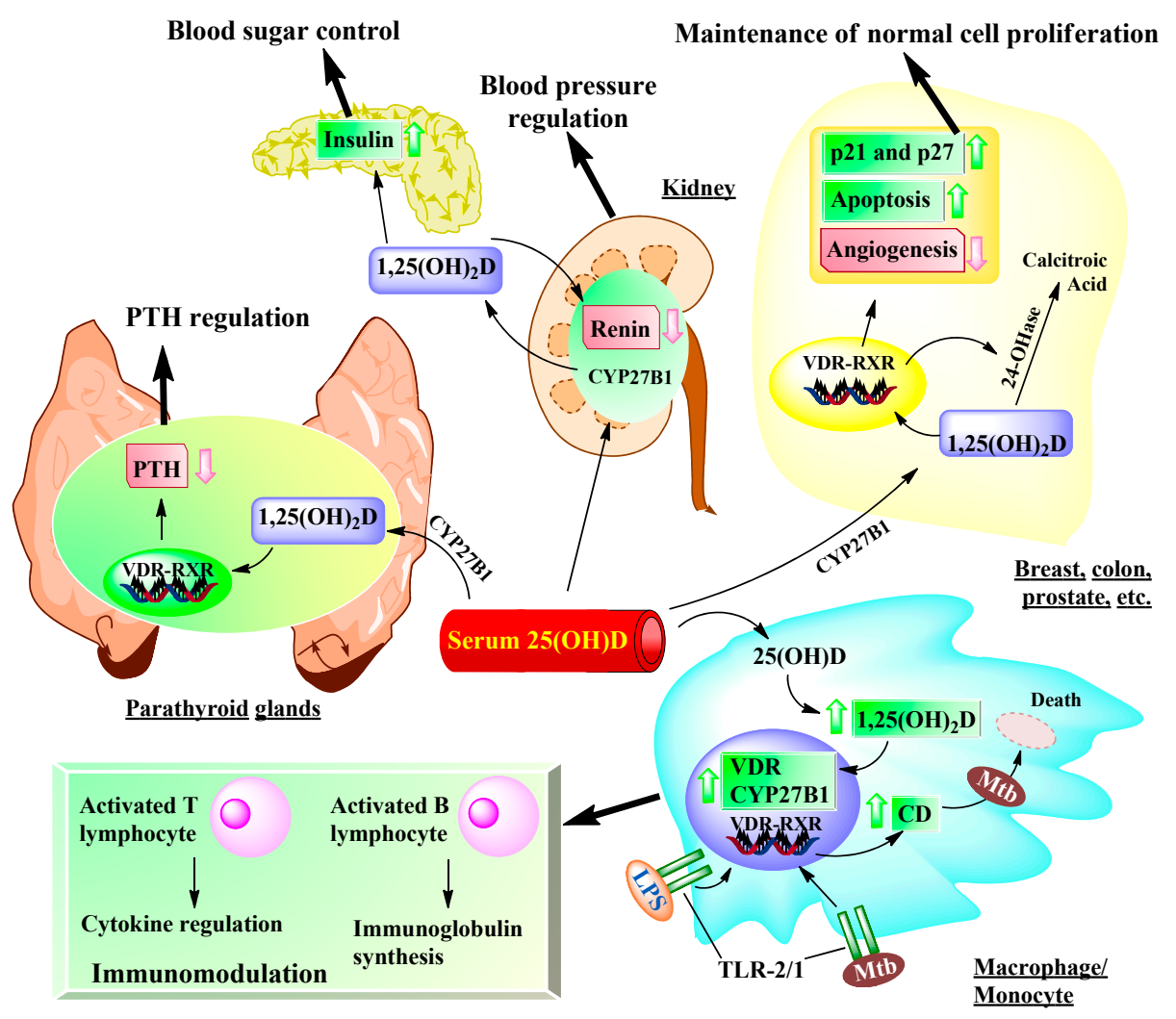

Figure 3. Metabolism of $25(\mathrm{OH}) \mathrm{D}$ to $1 \alpha, 25(\mathrm{OH})_{2} \mathrm{D}$ for non-musculoskeletal functions. $1 \alpha, 25(\mathrm{OH})_{2} \mathrm{D}$ 
not only regulates calcium and phosphorus homeostasis but can inhibit renin production in the kidney and stimulate the pancreas to secret insulin. $1 \alpha, 25(\mathrm{OH})_{2} \mathrm{D}$ can also be converted from $25(\mathrm{OH}) \mathrm{D}$ through autocrine production and interacts with VDR in the breast, colon, prostate, and other tissues to regulate a wide variety of genes that control proliferation (such as enhancing expression of p21 and p27), inhibit angiogenesis, and induce differentiation and apoptosis. It is believed that the regulation of cell growth and maturation is important for decreasing risk of the cell becoming malignant. The upregulation of VDR and CYP27B1 expression occurs after the activation of toll-like receptor 2/1 (TLR2/1) in a macrophage or monocyte by an infectious agent such as Mycobacterium tuberculosis $(M t b)$ or its lipopolysaccharide. This results in an increase in the nuclear expression of cathelicidin, a cationic peptide capable of promoting innate immunity and the destruction of the infectious agents. The regulation of cytokine synthesis and immunoglobulin synthesis by activated Tymphocytes and activated B lymphocytes, respectively, is associated with the $1 \alpha, 25(\mathrm{OH})_{2} \mathrm{D}$, which is locally produced in monocytes and macrophages.

\subsection{Immunomodulatory Functions}

The immunomodulatory functions of vitamin $\mathrm{D}$ were first described more than 30 years ago [132-134]. $1 \alpha, 25(\mathrm{OH})_{2} \mathrm{D}$ reduces the inflammatory response of $\mathrm{T}$ helper1 (Th1) cells and suppresses antigen presentation by dendritic cells (DCs), both of which are involved in the autoimmune response [135]. Autoimmunity arises when Th1 cells are misdirected against self-proteins. The vitamin $\mathrm{D}$ metabolite $1 \alpha, 25(\mathrm{OH})_{2} \mathrm{D}$ suppresses this pathology by regulating the differentiation and activity of $\mathrm{CD}^{+} \mathrm{T}$ cells, resulting in inhibition of the proliferation of Th1 cells [136]. $1 \alpha, 25(\mathrm{OH})_{2} \mathrm{D}$ can also inhibit the differentiation of the DCs and their antigen-presenting ability, which stimulates T cells [137-139]; reduce the polarization of Th0 cells to Th1 cells [140]; and the secretion of Th1 cytokines, such as interleukin (IL)-2, IL-12 and interferon $\gamma$ (IFN $\gamma$ ) [140-142]. Increased production of Th2 cytokines such as IL-4, IL-5, and IL-10 [143,144] has also been noted, which leads to a more balanced Th1/ Th2 response with less development of self-reactive T cells. Furthermore, $1 \alpha, 25(\mathrm{OH})_{2} \mathrm{D}$ can reduce B cell proliferation and their differentiation into plasma cells [145], and increase the activity of the regulatory $\mathrm{T}$ cells (Tregs), which play an important role in maintaining immunological self-tolerance [136]. The immunomodulatory effects of $1 \alpha, 25(\mathrm{OH})_{2} \mathrm{D}$ are summarized in Figure 4.

\subsubsection{Autoimmune Diseases}

Autoimmune diseases are caused by dysfunctions of the body's immune system leading to tissue damage. They are mediated by $\mathrm{T}$ and/or B cell activation in the absence of ongoing infection or other discernible causes [146]. The etiology and pathogenesis of most autoimmune disorders remain unclear and several factors have been implicated in their development. VDR was found in several cells and tissues in the immune system, such as lymphocytes, monocytes and DCs [147]. Numerous epidemiological studies, especially during the last decade, have reported an association between vitamin D deficiency and autoimmune diseases, including rheumatoid arthritis (RA), multiple sclerosis (MS), systemic lupus erythematosus (SLE), and inflammatory bowel disease (IBD) [136,148,149].

\section{Rheumatoid Arthritis}

RA is a chronic and systemic autoimmune disorder that primarily affects joints all around the body, including the wrists, hands, elbows, shoulders, knees, and ankles. RA may also develop into joint and tissue damage, resulting in severe disability and increased mortality [150]. Vitamin D's effects on the innate immune system are predominantly through the TLRs and on the adaptive immune system through T cell differentiation, particularly the Th17 cell response. As Th17 cells are critical in the pathogenesis of RA, this has led to an interest in the effects of vitamin D deficiency in RA [151]. Epidemiological and observational evidence suggests a greater incidence of RA with increasing latitude, similar to the amplified risk of vitamin D deficiency [136,152]. For example, a higher prevalence of 
RA and lower $25(\mathrm{OH}) \mathrm{D}_{3}$ level (plasma $25(\mathrm{OH}) \mathrm{D}_{3}<40 \mathrm{nmol} / \mathrm{L}$ ) are noted in patients from northern Europe compared with those in southern Europe [153].

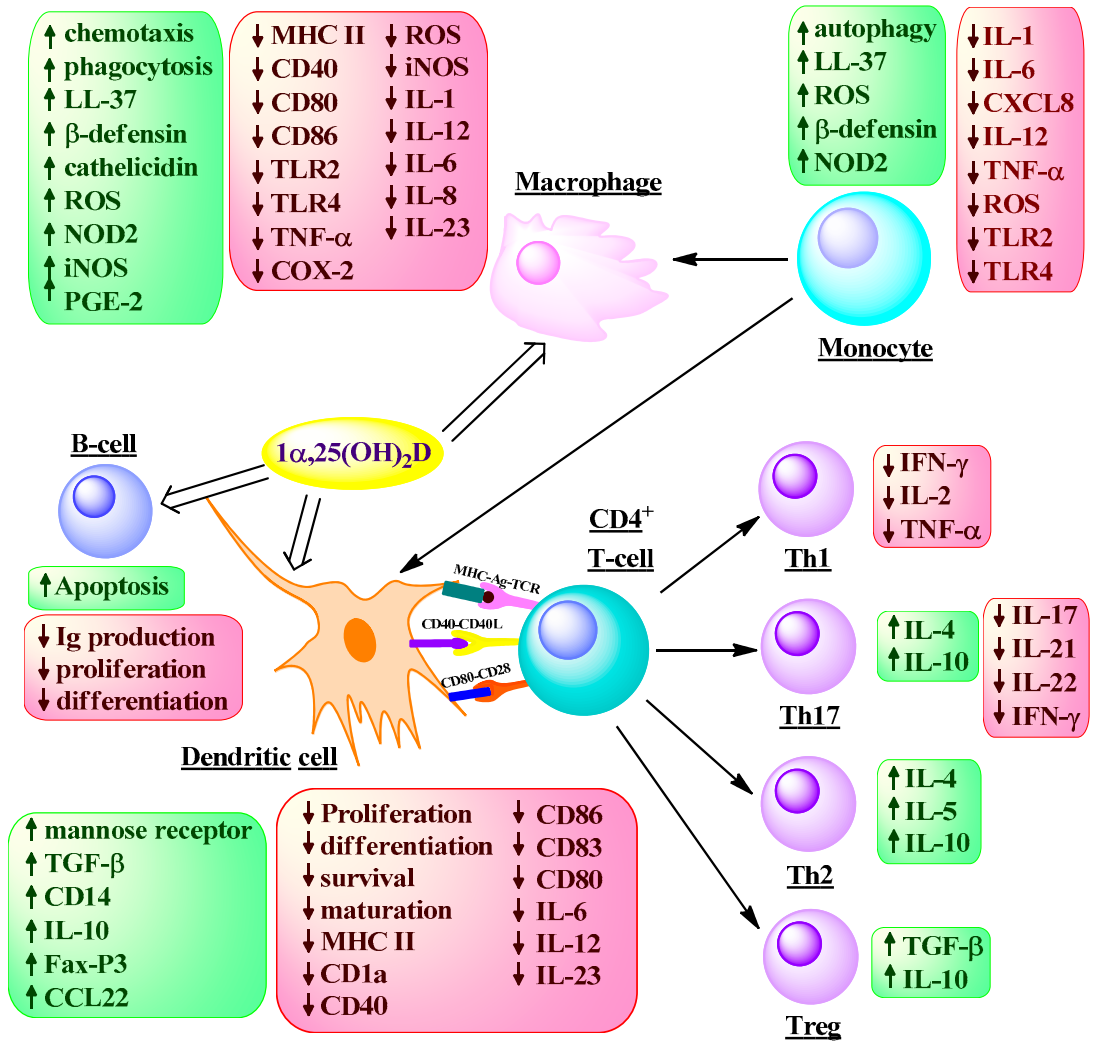

- Th1 response: Cell-mediated immunity, intracellular pathogens (viruses), auto-immune diseases

- Th17 response: Pro-inflammatory effect, auto-immunity, extracellular pathogens

- Th2 response: Antibody-mediated immunity, bacteria and parasites, allergic response

- Treg response: Effector $\mathbf{T}$ cell regulation, immune tolerance

Figure 4. Mechanisms for adaptive immune responses to $1 \alpha, 25(\mathrm{OH})_{2} \mathrm{D}$. Monocytes produce more LL-37 and $\beta$-defensin, enhance autophagy and NOD2 (nucleotide-binding oligomerization domaincontaining protein 2) expression, decrease the production of inflammatory cytokines and downregulate TLR2/4 expression. Differentiation into macrophages is increased; the chemotactic and phagocytotic responses of macrophages and the production of antimicrobial proteins such as cathelicidin are upregulated. However, the stimulatory capacity of the antigen-presenting cells (APCs) and T cells is decreased. At the level of the APC, $1 \alpha, 25(\mathrm{OH})_{2} \mathrm{D}$ inhibits the differentiation into $\mathrm{DCs}$, and thus stimulates effector $\mathrm{CD} 4^{+}$cells to differentiate into one of the four types of Th cells. Activated T cells also express VDR. $1 \alpha, 25(\mathrm{OH})_{2} \mathrm{D}$ inhibits the development of Th1 cells associated with the cellular immune response, and promotes Th2 cells associated with humoral (antibody) mediated immunity, thereby indirectly promoting the T cell shift from a Th1 towards a Th2 phenotype. $1 \alpha, 25(\mathrm{OH})_{2} \mathrm{D}$ also inhibits the development of Th17 cells, which play an essential role in combating certain pathogens and are linked to tissue damage and inflammation. Moreover, $1 \alpha, 25(\mathrm{OH})_{2} \mathrm{D}$ favors Treg cell development via modulating DCs and by directly targeting $\mathrm{T}$ cells. Finally, B cells are also affected by $1 \alpha, 25(\mathrm{OH})_{2} \mathrm{D}$, demonstrating decreased immunoglobulin production, proliferation and differentiation, but increased apoptosis.

In an animal model study on the influence of the absence of vitamin D signaling in chronic arthritis, clinical symptoms of arthritis were aggravated in the VDR-deficient human tumor necrosis factor (TNF) transgenic mice. [154] Another study also found that the mice fed a diet supplemented with $1 \alpha, 25(\mathrm{OH})_{2} \mathrm{D}$ had a $50 \%$ lower prevalence of collageninduced arthritis compared to the control mice. [155] A recent meta-analysis and systematic review [156] analyzed 24 reports before May 2015 involving a total of 3489 patients. Overall, 
a negative association between serum vitamin D and RA activity was observed. Another systematic review and meta-analysis [157] identified five RCTs of vitamin D supplementation for at least 3 months $(n=640)$ and demonstrated that vitamin D supplementation could possibly reduce RA activity and its recurrence. However, inadequate randomization and allocation in some RCTs and relatively small sample numbers for the meta-analysis compromise the reliability of these data. In contrast, a cross-sectional study [158] performed on 100 RA patients (18 to 75 year-olds) with 25(OH)D tests within the prior 3 months found no statistically significant relationship between the $25(\mathrm{OH}) \mathrm{D}$ level and RA activity. Although vitamin D deficiency is more frequent among patients with RA [159], results published to date appear insufficient to fully elucidate the immunomodulatory role of vitamin D.

\section{Inflammatory Bowel Disease}

IBD is a group of chronic inflammatory conditions of the colon and small intestine, principally comprising CD and ulcerative colitis (UC). IBD is hypothesized to occur as a result of an abnormal immune response to enteric bacteria in genetically susceptible individuals [160]. A study on IL-10 knockout mice revealed that a low level of vitamin D was associated with accelerated bowel inflammation, while vitamin $\mathrm{D}_{3}$ supplementation ameliorated IBD symptoms in these mice [161,162]. In a double-blind RCT including 94 patients with $\mathrm{CD}$ in remission, daily oral treatment with $1200 \mathrm{IU}$ of vitamin $\mathrm{D}_{3}$ increased the mean serum $25(\mathrm{OH}) \mathrm{D}_{3}$ concentration from 69 to $96 \mathrm{nmol} / \mathrm{L}$ and reduced the relapse rates over the 1-year follow-up $(13 \%$ vs. $29 \%$; $p=0.06)$ compared to the placebo group [163]. A systematic review and meta-analysis [164] identified 27 studies before February 2018 comprising 8316 IBD patients ( $3115 \mathrm{UC}, 5201 \mathrm{CD}$ ) and provides evidence that 25(OH)D status is negatively correlated with the odds of IBD activity. Another systematic review and meta-analysis [165] including 18 RCTs $(n=908)$ from 1978 to 2018 concluded that vitamin $\mathrm{D}$ treatment in IBD patients can control the relapse rate of the disease. However, significant heterogeneity-vitamin dosage and treatment course; racial and regional diversity; age range and sex ratio-among the trials influence the judgments. Thus, more high-quality RCTs are still needed for evaluation.

\section{Multiple Sclerosis}

MS is an autoimmune disorder that affects the central nervous system. The body attacks its own insulating myelin sheaths covering the nerve cells in the brain and spinal cord, resulting in the partial impairment of the nervous system regarding communication, loss of motor and / or sensory function, lack of coordination, cognitive decline, and mental and psychiatric illness [166-168]. Although the exact etiology of MS is still unknown, oxidative stress resulting from reduced nicotinamide adenine dinucleotide phosphate oxidase (NOX) activation is thought to exacerbate the active demyelination and neurodegeneration in MS $[169,170]$. The increased reactive oxygen species (ROS) which are generated by the activation of NOX [171], will result in damage to the mitochondria to generate further ROS [170,172]. This buildup of ROS can reduce the efficiency of glutamate transporters, leading to raised glutamate concentrations and consequently enhancement in excitotoxic damage [173]. Additionally, the inevitable increase in $\mathrm{Ca}^{2+}$ will activate the permeability transition pores, resulting in apoptosis [172].

In mesencephalic dopaminergic neurons, vitamin D can alleviate ROS-induced neurotoxicity by increasing the level of glutathione [174]. There is increasing genetic evidence to suggest that vitamin D deficiency is an important risk factor in MS [175-178]. One study showed that vitamin D regulates $>80 \%$ of MS-related genes. A probable reason that lower levels of $1 \alpha, 25(\mathrm{OH})_{2} \mathrm{D}$ resulting from CYP27B1 mutations can give rise to disruptions to the critical gene-environment interactions important for the developing immune or nervous system, which then predispose one to MS, has been suggested [179]. In brief, genetic polymorphisms within key enzymes involved in vitamin D metabolism, and within the VDR, have been associated with the risk of developing MS [180]. 
Low serum 25(OH)D levels $(\sim 20 \mathrm{ng} / \mathrm{mL})$ are usually observed in MS patients as early as the beginning of the disease [181]. In a recent prospective cohort study (170 natalizumabtreated patients with relapsing-remitting MS) [182], blood samples were collected during winter 2009-2010 (baseline) with follow-up during the subsequent winter. It was found that recommending oral vitamin $\mathrm{D}$ supplements in patients with vitamin $\mathrm{D}$ insufficiency was associated with a significant increase in serum $25(\mathrm{OH}) \mathrm{D}$ level $(95 \% \mathrm{CI},-0.026$ to $-0.003)$ and decreases in the annualized relapse rate $(p=0.02)$. In contrast, a retrospective study [183] including 554 MS patients over three years of follow-up only observed a significant correlation between $25(\mathrm{OH}) \mathrm{D}$ status and the subsequent relapse risk in younger MS patients $(\leq 37.5$ years; $\mathrm{OR}=0.872$, per $10 \mathrm{nmol} / \mathrm{L} 25(\mathrm{OH}) \mathrm{D}, p=0.041)$, while no relationship was found between serum $25(\mathrm{OH}) \mathrm{D}$ level and disability or disability progression. As heat aggravating the MS symptoms results in fewer outdoor activities and consequently less exposure to UVB in disabled patients, the reverse causality makes it more difficult to interpret the results. However, vitamin D supplementation in moderate doses for MS patients is recommended for essentially correcting their vitamin insufficiency.

\section{Asthma}

Asthma is a common chronic inflammatory disease of the airways of the lungs. It is characterized by bronchospasm; reversible airflow obstruction; and variable and recurring symptoms, including episodes of wheezing, coughing, chest tightness, and shortness of breath [184]. Although the role of vitamin D in asthma is not currently well understood, some putative correlations between vitamin $\mathrm{D}$ and asthma have been reported. Significant associations between polymorphisms in the VDR gene with asthma have been reported in several genetic association studies, but this has not been consistently replicated [185-187]. It was also observed that children who took vitamin $\mathrm{D}$ daily had a relative risk reduction of $93 \%$ for having asthma attacks compared with children who did not take vitamin D supplements [188]. A community-based prospective study on the transition of children to an allergic asthma phenotype showed that $25(\mathrm{OH}) \mathrm{D}_{3}$ levels at ages 6 and 14 were negatively associated with concurrent allergic phenotypes, particularly in boys. Vitamin D levels at age 6 were also significant predictors of subsequent atopy/asthma-associated phenotypes at 14 years of age [189]. Potential mechanisms of the action of vitamin D might include promoting lung immunity, decreasing inflammation, slowing cell cycling, reducing hyperplasia, and enhancing the effects of exogenous steroids [190].

However, a number of pieces of evidence were not consistently supportive of a causal role for vitamin $\mathrm{D}$ in reducing the risk of asthma. In a nested case-control study, no association between baseline serum $25(\mathrm{OH}) \mathrm{D}$ concentration $<50 \mathrm{nmol} / \mathrm{L}$ and asthma in men $(\mathrm{OR}=1.47 ; 95 \% \mathrm{CI}, 0.93-2.32)$ or women $(\mathrm{OR}=0.94 ; 95 \% \mathrm{CI}, 0.67-1.32)$ was noted [191]. Data from a study on the prospective associations of $25(\mathrm{OH}) \mathrm{D}_{2}$ and $25(\mathrm{OH}) \mathrm{D}_{3}$ with asthma, wheezing, flexural dermatitis, and lung function in children showed interesting results. It is likely that higher serum $25(\mathrm{OH}) \mathrm{D}_{2}$ concentration was associated with reduced risks of wheezing and flexural dermatitis and better lung function, while serum $25(\mathrm{OH}) \mathrm{D}_{3}$ concentration was positively associated with wheezing and flexural dermatitis. No correlation was found between $25(\mathrm{OH}) \mathrm{D}_{3}$ or total $25(\mathrm{OH}) \mathrm{D}$ concentration and diagnosed asthma or lung function [192]. A systematic review of observational studies assessing relationships between maternal vitamin $\mathrm{D}$ intake during pregnancy $(n=4)$, maternal serum $25(\mathrm{OH}) \mathrm{D}$ concentration in pregnancy $(n=2)$ or cord blood $25(\mathrm{OH})$ D concentration $(n=2)$ and asthma, reported conflicting results that make it difficult to establish any clear relationship between maternal serum 25(OH)D concentration and the development of asthma in offspring [193].

\section{Type 1 Diabetes (T1D)}

T1D, an autoimmune disorder which induces loss of insulin-producing $\beta$-cells in the pancreas, is usually diagnosed in children and younger adults. It has been postulated that immune-modulatory actions of vitamin $\mathrm{D}$ decrease the cytokine production and lymphocyte proliferation, thereby preventing the destruction of $\beta$ cells and subsequent de- 
velopment of T1D [194-196]. An association has been noted between VDR polymorphism and T1D in several genetic studies [197-199]. Polymorphism in the CYP27B1 gene was found to reduce the level of active $1 \alpha$-hydroxylase, and subsequently suppress the conversion of $25(\mathrm{OH}) \mathrm{D}$ to $1 \alpha, 25(\mathrm{OH})_{2} \mathrm{D}$, resulting in an increased predisposition to T1D [200]. There is also a large body of evidence linking a lack of vitamin D early in life to the development of T1D. In vivo studies have shown that vitamin D deficiency leads to decreased insulin production from pancreatic $\beta$ cells, leading to impaired glucose tolerance [201]. Vitamin D supplementation during infancy was reported to confer partial protection against $\beta$-cell autoimmunity [202]. The risk of islet cell antibodies in offspring was decreased by $63 \%$ with a single standard deviation (156 IU) increase in recalled maternal dietary vitamin D intake during pregnancy [203]. Similarly, higher intake of maternal cod liver oil, a source of vitamin $\mathrm{D}$, was associated with a decreased risk of type 1 diabetes in offspring during pregnancy [204].

\section{Systemic Lupus Erythematosus}

SLE is a common autoimmune disease in which the body's immune system produces antibodies against its own healthy tissues. These autoantibodies specific for DNA, RNA or proteins bind to nucleic/amino acids to form immune complexes, which contribute to the damage of small blood vessels, especially in the kidneys. Patients with SLE generally have abnormal $\mathrm{B}$ and $\mathrm{T}$ cell function, along with rashes, arthritis, kidney disease and central-nervous-system involvement [203].

Higher severity of SLE has been shown to be associated with lower levels of vitamin $D$ [205]. However, whether lower vitamin D levels cause disease or are a consequence of the disease or its treatment is not clear. Vitamin D deficiency could be due to many factors in these patients, such as frequent use of photoprotection, since the patients are usually photosensitive, chronic steroid use causing a variation in vitamin D metabolism, renal involvement from SLE resulting in decreased hydroxylation of $25(\mathrm{OH}) \mathrm{D}$ or the formation of anti-vitamin D antibodies in a subset of patients with SLE [205].

In murine models of experimental SLE, administration of $1 \alpha, 25(\mathrm{OH})_{2} \mathrm{VD}_{3}$ or an ana$\log$ prevented proteinuria and increased the life spans of mice [135,206,207]. An in vitro experiment on the treatment of peripheral blood mononuclear cells isolated from 25 SLE patients with $50 \mathrm{nM}$ of $1 \alpha, 25(\mathrm{OH})_{2} \mathrm{VD}_{3}$ showed that vitamin $\mathrm{D}$ has regulatory effects on cell cycle progression, apoptosis and apoptosis-related molecules in lupus patients [208]. In addition to its potential benefit to SLE patients, vitamin D is known to present an immune-inflammatory-modulatory effect that can benefit musculoskeletal and cardiovascular manifestations of SLE [209]. The results from one investigation demonstrate that vitamin $\mathrm{D}$ can positively modify endothelial repair mechanisms and thus endothelial function in SLE patients that are susceptible to CVDs [210]. Other than vitamin D levels, VDR gene polymorphisms may also play a role in the risk of SLE. A recent meta-analysis concluded that BsmI B may be a risk factor for SLE onset for the overall population and that the FokI FF genotype is a risk factor in Asians for SLE susceptibility [211]. This was further confirmed by a recent follow-up study, which found a positive association between VDR polymorphisms and SLE severity, especially for the FokI CT and TaqI TT genotypes in 170 SLE patients [212]. Conversely, it has been shown that increasing levels of vitamin D intake were not associated with decreased risk of developing SLE in the Nurses' Health Study for up to 22 years of follow-up of 186.389 women [213].

\subsubsection{Innate Immunity and Infectious Diseases}

In the days when rickets was rampant, children with this disorder were at higher risk of death from respiratory infections $[46,214]$. Vitamin $D$ in its autocrine role has been recognized for more than 20 years as playing a role in modulating the innate immune response, and its deficiency is related to plenty of infectious diseases, such as tuberculosis, pneumonia, influenza, septicemia and periodontal disease [214-216]. This possible role has been suggested by the presence of VDRs and CYP27B1 in various cells of the immune 
system, including $\mathrm{B}$ and $\mathrm{T}$ lymphocytes, macrophages and DCs. Upregulation of the expression of both CYP27B1 and VDR, involved in the initiation of antimicrobial responses, requires adequate levels of vitamin $\mathrm{D}[217,218]$. When the cells of the immune system such as macrophages ingest an infectious agent, such as tuberculosis bacillus, the TLRs are activated, resulting in signal transduction to increase the expression of VDR and CYP27B1. In turn, CYP27B1 gene enhances the local conversion of $25(\mathrm{OH}) \mathrm{D}$ to $1 \alpha, 25(\mathrm{OH})_{2} \mathrm{D}$, which subsequently acts in an autocrine/paracrine manner through VDR. This increases the formation of antimicrobial peptides such as cathelicidin and defensin beta 4 that facilitate the killing of mycobacteria [218]. Other roles vitamin D plays in the maturation of macrophages include the production of macrophage-specific surface antigens and the secretion of the lysosomal enzyme acid phosphatase and hydrogen peroxide [147]. Together with the enhancement of the transcription of endogenous antibiotics such as cathelicidin and defensins, these explain why vitamin D possesses antimicrobial activity despite it inhibiting immune reactions in general.

Cell studies have proposed that the infected macrophage is unable to produce sufficient $1 \alpha, 25(\mathrm{OH})_{2} \mathrm{D}$ to upregulate production of cathelicidin in cases of vitamin D deficiency, and higher $1 \alpha, 25(\mathrm{OH})_{2} \mathrm{D}$ levels enhanced the bactericidal activity of human macrophages against $M t b$ [219]. In a murine model of heart allograft, $1 \alpha, 25(\mathrm{OH})_{2} \mathrm{D}$ and one of its analogs prolonged allograft survival, suggesting that vitamin D might be used as adjuvant therapy in association with immunomodulating drugs in organ transplantation [220]. Clinically, it has been noted in RCTs that vitamin D co-therapy substantially improved the response to standard antitubercular therapy in patients with advanced pulmonary tuberculosis [221], and as a secondary outcome, reduced risk for influenza in postmenopausal black women who received vitamin D [222]. Additionally, the phagocytic function of human macrophages was enhanced in individuals who received vitamin D supplementation (a single oral dose of $2.5 \mathrm{mg}$ ) compared to those who took a lactose placebo [223].

\section{Vitamin D and COVID-19}

The world is in the grip of the COVID-19 pandemic, which has had over 100 million confirmed cases and over 2 million deaths in 216 countries worldwide (as of 10 February 2021; World Health Organization). The leading cause of death is acute respiratory distress syndrome (ARDS), since the lungs are a major target for COIVD-19 virus. ARDS is mainly caused by a "cytokine storm," a hyperactive immune response triggered by the infection and further magnified by attendant oxidative stress. The immune cells release all types of cytokines, such as IFNs, ILs, chemokines, colony-stimulating factors and TNF, leading to hyperinflammation, lung damage and mortality. In severe cases of COVID-19, other organs and systems are also damaged [224].

Recently, vitamin D deficiency has emerged as a potential risk factor predisposing one to COVID-19 [224,225]. Pulmonary alveolar macrophages are induced to express CYP27B1 and the vitamin $\mathrm{D}$ receptor by pathogens [226]. $1,25(\mathrm{OH})_{2} \mathrm{D}$ can regulate the innate immune response through a number of mechanisms, including suppression of IL-6 production by innate monocytes [227], which have recently been identified as being involved in the atypical innate immune responses induced by COVID-19 [228,229]. 1,25(OH $)_{2} \mathrm{D}$ also downregulates TLRs and directly inhibits TNF/NFKB and IFN $\gamma$ signaling pathways. As for adaptive immunity, $1,25(\mathrm{OH})_{2} \mathrm{D}$ limits the DC maturation and the ability of DCs to present antigen to $\mathrm{T}$ cells, and shifts the $\mathrm{T}$ cell profile from the proinflammatory Th1 and Th17 subsets to Th2 and Treg subsets, leading to proinflammatory inhibition [226]. The administration of vitamin $\mathrm{D}$ in a study showed that it could reduce the expression of renin, angiotensin II and angiotensin 1 receptors and increase angiotensin-converting enzyme 2 and angiotensin activities, resulting in reduction of the inflammatory process and lung damage [230]. Albeit most results come from studies with a variety of pathogens, viral and bacterial, the effect of vitamin D on regulating COVID-19 lung immunopathology needs to be rigorously evaluated in the future. A systematic meta-analysis [231] of 25 RCTs found that vitamin D protected against acute respiratory tract infection. Several other systematic 
reviews and meta-analyses [232-235] observed a potentially positive association between vitamin D deficiency and COVID-19 infection, severity and mortality. However, additional evidence with larger populations and prospective study designs in RCTs are needed for further evaluation.

\subsection{Cancers}

Observations have demonstrated increases in risks of developing several cancers and cancer mortality with increasing latitude, and longer survival for patients diagnosed with certain malignancies during summer months than winter months [236,237]. Since the intensity of sun exposure decreases with increasing latitude, and on the basis that sun exposure is a proxy for vitamin D status, it was first suggested that vitamin D might influence cancer by Garland and Garland [238]. They proposed that the high rate of colon cancer seen in the Northern US compared with the Southern US was due to the UV light-induced production of vitamin D in the skin. Later, the hypothesis was extended to 18 different types of cancer [239]. This is also evidenced by some cell culture studies and animal studies. It was observed that $1 \alpha, 25(\mathrm{OH})_{2} \mathrm{D}_{3}$ inhibited growth of malignant cell culture lines $[240,241]$ and that reductions in tumor development and growth occurred in animals injected with $1 \alpha, 25(\mathrm{OH})_{2} \mathrm{D}_{3}$ analogs [242-246]. In addition, some other animal studies have shown that severe vitamin D deficiency $[243,247,248]$, or deletion of the VDR gene [249-251], increases cancer risk.

The proposed mechanisms of vitamin D's anticancer effects via transcriptional regulation mainly encompass: (1) anti-proliferation, (2) induction of apoptosis, (3) stimulation of differentiation, (4) reduced inflammation, (5) inhibition of invasion and metastasis, and (6) inhibition of angiogenesis [252]. Anti-tumor studies of $1 \alpha, 25(\mathrm{OH})_{2} \mathrm{D}_{3}$ and vitamin $\mathrm{D}$ analogs in different types of cancer cell lines are classified by each of these effects and summarized in the Supporting Information (Table S1).

Some population-based studies show that low serum $25(\mathrm{OH}) \mathrm{D}$ levels are associated with increased risks of cancers of the colon [253-257], breast [258,259], and prostate [260,261], and other cancers [262-264]. However, together with cell culture and animal studies, although a growing consensus insists that vitamin D is closely related to cancer risk, some population-based studies showed inconsistent associations. One cohort study followed white adults ( $n=1621$; mean age, 74 years) in the US for a median of 11 years and reported no association between seasonally adjusted serum $25(\mathrm{OH}) \mathrm{D}$ concentration and cancer [265]. Vitamin D's effects on cancer were also evaluated in the "VITamin D and OmegA-3 TriaL (VITAL)," an RCT in 25,871 older participants in the United States who were randomized to 2000 IU of vitamin D daily, $1 \mathrm{~g}$ of omega-3 daily or placebo [266]. After a median follow-up time of 5.3 years, it was concluded that supplementation with vitamin $\mathrm{D}$ did not result in a lower incidence of invasive cancer than placebo. Interestingly, an inverse relationship between $25(\mathrm{OH}) \mathrm{D}$ level and cancer risk was also observed. A meta-analysis reported that higher serum $25(\mathrm{OH}) \mathrm{D}$ concentration was associated with significant increases in risk in basal cell skin cancer and non-melanoma skin cancer [267]. Stolzenberg-Solomon and co-authors reported a significant increase in pancreatic cancer risk associated with higher $(\geq 100 \mathrm{nmol} / \mathrm{L})$ compared to lower $(<25 \mathrm{nmol} / \mathrm{L})$ serum $25(\mathrm{OH}) \mathrm{D}$ concentration [268].

The studies are, however, subject to confounding by behavioral and lifestyle factors that influence serum $25(\mathrm{OH}) \mathrm{D}$ concentrations, and the conflicting results made it difficult to conclude any relationship between vitamin $\mathrm{D}$ and cancer risk. In the large control population of the "Cohort consortium vitamin D pooling project of rarer cancers," including men and women from US, Chinese and Finnish cohorts, several correlates of serum $25(\mathrm{OH}) \mathrm{D}$ concentration were measured [269]. Statistically significant positive correlates of serum $25(\mathrm{OH}) \mathrm{D}$ concentration included male sex, vigorous physical activity, and alcohol intake. Significant inverse correlates were BMI, diabetes, sedentary behavior, and smoking. Data from two studies showed that gender and ethnic background seem to affect this association too. One study followed adults in Germany ( $n=9580$; age, 50-74 years) for more than 8 years and reported an association between low serum 25(OH)D concentration 
(season-specific ranges, 30-36 nmol/L) and increased risk for any cancer in men but not in women [270]. Another study of five ethnic groups in the US (white, African American, Native Hawaiian, Japanese, and Latino) reported an inverse association between breast cancer risk and $25 \mathrm{nmol} / \mathrm{L}$ increases in plasma $25(\mathrm{OH}) \mathrm{D}$ concentration $(\mathrm{OR}=0.66 ; 95 \% \mathrm{CI}$, 0.48-0.90) in whites but not in other ethnic groups [259].

\subsection{Cardiovascular Diseases}

CVDs include a range of diseases of the heart and blood vessels, such as coronary artery diseases, congenital heart disease, stroke, hypertension, and vascular dementia [271]. Smoking, high blood pressure, high blood cholesterol, excessive alcohol consumption, physical inactivity, obesity, diabetes, family history, sex, and age are common risk factors for CVDs [271]. CVDs are predominantly caused by atherosclerotic deposits in large and medium-sized arteries. Besides lipid deposition and inflammation, calcification is also a significant component of advanced atherosclerotic lesions. Therefore, the impact of calcium intake in relation to atherosclerotic CVD should be taken into consideration. Since vitamin $\mathrm{D}$ has the potential to increase calcium absorption in the presence of high calcium intakes, it is also biologically plausible that vitamin D might increase vascular calcification, and as a consequence, increase CVD risk. Indeed, available data demonstrate that vitamin $D$ exerts a biphasic dose-response curve (a " $U$ " curve) on vascular calcification with the negative consequences of not only vitamin D excess but also of vitamin D deficiency [272]. However, both lower and upper boundaries of the optimal range for $25(\mathrm{OH}) \mathrm{D}$ levels for cardiovascular health remain controversial.

VDRs now are known to exist in heart and vascular tissue where they regulate the expression of multiple genes. Vitamin D deficiency has been found in multiple populations with CVD risk factors, and another study suggested that vitamin D deficiency is a risk factor itself for developing CVDs $[130,273]$. Several lines of evidence have been suggested in support of a biologically plausible relationship between serum $25(\mathrm{OH}) \mathrm{D}$ concentration and cardiovascular events. A murine model has shown that VDR knockout mice develop heart failure despite normalized calcium concentrations [274]. Some other animal studies have also suggested a link between ingested vitamin D and atherosclerosis [275,276].

In a prospective study, a decreased risk of coronary heart disease (CHD) was found to associate with serum 25(OH)D concentrations (>47.7 nmol/L), significantly in women [277]. In addition, Robinson-Cohen and coauthors reported that lower $25(\mathrm{OH}) \mathrm{D}$ concentrations were associated with increased CHD risk in white and Chinese participants but not in black and Hispanic participants [278]. Conversely, a few prospective cohort studies reported no association between serum 25(OH)D concentration and CVD incidence $[266,279,280]$.

A leading explanation for a relationship between vitamin D deficiency and CVD is that chronic vitamin D deficiency leads to secondary hyperparathyroidism, which then can act through at least three pathogenic pathways to increase CVD risk: (1) increased insulin resistance and pancreatic $\beta$-cell dysfunction, predisposing one to metabolic syndrome and diabetes; (2) activation of the renin-angiotensin system, increasing blood pressure and leading to left ventricular hypertrophy (with subsequent myocyte apoptosis and cardiac fibrosis); (3) stimulation of systemic and vascular inflammation, augmenting atherogenesis [281,282]. In hemodialysis patients with secondary hyperparathyroidism, intravenous treatment with $1 \alpha, 25(\mathrm{OH})_{2} \mathrm{D}$ was found to significantly reduce myocardial hypertrophy [283]. This might be due to the effect of $1 \alpha, 25(\mathrm{OH})_{2} \mathrm{D}$ on the myocardium or renin-angiotensin system, or the direct effect of PTH on the heart muscle.

However, data from some studies show that PTH elevation appears to explain only part of the association of CVD risk with vitamin D deficiency. [284,285]. Some other non-PTH-related CVD mechanisms have proposed that vitamin D can affect blood pressure through the reticular activating system, vascular calcification, smooth muscle cell proliferation, and inflammation [286]. Additional recent evidence suggests that vitamin D supplementation may reduce endothelial dysfunction and arterial stiffness, and thus improve vascular function [287]. Further, it has been reported that high $25(\mathrm{OH}) \mathrm{D}$ levels 
can protect against cardiovascular risk by promoting the formation of large high-density lipoprotein particles, affecting reverse cholesterol transport [288]. Other molecular mechanisms of CVD likely await discovery.

\subsection{Neuropsychological Functioning}

Neuropsychological functioning, encompassing cognitive function, depression, dementia, autism, and schizophrenia, involves specific psychological processes and behaviors regulated by brain function. The effect of vitamin $\mathrm{D}$ on brain function is an area of growing interest, as the role of vitamin D in brain function is becoming clearer. [289,290]. From a biological perspective, vitamin $\mathrm{D}$ receptors and $1 \alpha$-hydroxylase have been identified in the cerebral cortex and cerebellum. This suggests that the brain has the ability to synthesize $1 \alpha, 25(\mathrm{OH})_{2} \mathrm{D}$ within many cell types and regions, predominantly in the hypothalamus and the large neurons within the substantia nigra [291]. Functionally, vitamin D contributes to neuroprotection by modulating the production of nerve growth factor [291], neurotrophin [292], glial cell-derived neurotrophic factor [293], nitric oxide synthase [294], and choline acetyltransferase [295]. This provides the possibility that vitamin D might impact various aspects of brain function (such as mood and cognition) and diseases caused by abnormal brain function (such as autism and schizophrenia).

Animals deprived of vitamin D early in development show evidence of abnormal brain development [296]. Data from those studies have shown that after administration of selective dopamine toxins, such as 6-hydroxydopamine, pretreating animals with $1 \alpha, 25(\mathrm{OH})_{2} \mathrm{D}$ for one week still preserves dopaminergic function, indicating vitamin D may also have a neuroprotective effect on dopaminergic pathways in the brain $[297,298]$. A systematic review of observational studies including 25 cross-sectional $(n=48,680)$ and six prospective studies $(n=10,896)$ [299] assessed the association between serum 25(OH)D concentration and cognitive function; 18 out of 25 cross-sectional studies reported a significant decline in one or more cognitive function test or a higher frequency of dementia with lower vitamin D levels or intake. Four out of six prospective studies showed a higher risk of a worse outcome after a follow-up period of 4-7 years in participants with lower vitamin D levels at baseline. Other studies failed to show an association.

\subsection{UV-Induced Damage}

As indicated above, humans once depended on sunlight for their vitamin $\mathrm{D}$ requirements. Although cutaneous vitamin $\mathrm{D}_{3}$ synthesis is a major benefit from UV irradiation, other vitamin D-independent positive effects exist, such as reducing blood pressure by induction of nitric oxide, and elevating energy and mood through the release of endorphins [300]. However, UV is also known to be responsible for approximately $65 \%$ of melanoma cases, and $90 \%$ of non-melanoma skin cancers [301]. It is well established that UV radiation causes promutagenic DNA lesions in the skin directly by creation of genotoxic free radicals. These radicals disrupt double bonds in adjacent pyrimidines and thus distort the DNA helix [302]. The UV-induced DNA damage also occurs indirectly by generation of ROS and reactive nitrogen species (RNS). These species are known to cause oxidative and/or nitrosative damage to DNA, leading to alteration of the coding sequence, and thus tumor growth and progression [303]. Overexposure to UV radiation leads to photoimmune suppression [304,305], which depresses cell-mediated immune reactions that would normally destroy developing skin tumors [306,307]. Photoaging of the skin via wrinkles and dyspigmentation, followed by the formation of benign or malignant tumors, is also a consequence caused by UV irradiation [308].

The photoprotective effect of vitamin D compounds against UV-induced photoproducts such as thymine dimers in solar irradiated skin has been reported by various groups [309-311]. Reduction of two other major UV-induced photolesions, 8-oxo-7,8dihydro-2'-deoxyguanosine and 8-nitroguanine by $1,25(\mathrm{OH})_{2} \mathrm{D}_{3}$ in irradiated human ex vivo skin explants was also demonstrated [310]. 1,25(OH $)_{2} \mathrm{D}_{3}$ has been shown to enhance DNA repair, reduce inflammation and improve cell survival by reducing RNS such as ni- 
trite and 3-nitrotyrosine and augment p53 expression [312]. 1,25(OH $)_{2} \mathrm{D}_{3}$ was also found to have a regulatory effect on the transcription factor AP-1 and MMPs via the VDR and attenuated TNF- $\alpha$ induced MMP3, thereby probably reducing UV-induced collagen degradation in skin [313].

\section{Vitamin D Toxicity}

Vitamin D toxicity can lead to hypercalcemia and hypercalciuria caused by increased intestinal calcium absorption and mobilization of calcium from the bone. These toxic effects include calcification of soft tissue, diffuse demineralization of bones, and irreversible renal and cardiovascular disorders [314,315]. The mechanism of how vitamin D toxicity might arise is presently unclear. Proposed mechanisms are based on increased concentrations of the active metabolite of vitamin D reaching the VDR in the nuclei of target cells and causing gene overexpression. Three main hypotheses have been proposed [316]: increased plasma $1 \alpha, 25(\mathrm{OH})_{2} \mathrm{D}$ concentrations lead to increased cellular concentrations of $1 \alpha, 25(\mathrm{OH})_{2} \mathrm{D}$; serum $25(\mathrm{OH}) \mathrm{D}$ levels exceed DBP binding capacity and free $25(\mathrm{OH}) \mathrm{D}$ enters the cells and has direct effects on gene expression; concentrations of a number of vitamin $\mathrm{D}$ metabolites, especially vitamin D itself and $25(\mathrm{OH}) \mathrm{D}$, exceed the DBP binding capacity, causing release of free $1 \alpha, 25(\mathrm{OH})_{2} \mathrm{D}$, which enters target cells.

In fact, prolonged sunlight exposure does not lead to excess production of cutaneous vitamin $D$ because endogenously produced previtamin $D_{3}$ and vitamin $D_{3}$ are destroyed by the sun [317]. The only cause of toxicity is due to nonintentional or intentional ingestion of excessively high quantities of vitamin D for a prolonged period of time [318,319]. Cases of vitamin D toxicity resulting from ingestion of over-fortified milk have also been reported [320,321]. However, indeed, there is a comfortable safety margin between vitamin $\mathrm{D}$ toxicity and the intakes required for optimal vitamin $\mathrm{D}$ status. A risk assessment for vitamin D reviewing the totality of the toxicity data concluded that there were no cases of intoxication reported for daily intakes of $<30,000 \mathrm{IU}$ for extended periods or at serum 25(OH)D levels < $200 \mathrm{ng} / \mathrm{mL}(500 \mathrm{nmol} / \mathrm{L})$ [315].

\section{Conclusions}

Vitamin D has extensive and exciting potential and its potential benefits are under exploration. Despite the remarkable progress made recently, the available evidence on the relationship between vitamin $\mathrm{D}$ and health is far from complete. One limiting factor of the studies is that the existing $25(\mathrm{OH}) \mathrm{D}$ assays are excessively variable, and the lack of a standard reference material exacerbates this problem. The findings from these studies should be interpreted with caution, since several behavioral and lifestyle factors, such as smoking and diet, can influence the serum 25(OH)D concentrations as well. Indeed, only a few studies took confounders including baseline vitamin D status, BMI, age, pubertal stage, season, sickness, compliance and physical activity into consideration. These biases can be neglected by randomly assigning thousands of participants to receive or not receive the treatment. Biological flaws, referring to limitations in the design of primary studies that prevent the evaluation, also constitute a possible reason that meta-analyses of vitamin $\mathrm{D}$ have failed to demonstrate efficacy [322]. Due to the limitations in the evidence concerning vitamin D, further genomic investigations and functional studies in larger groups need to be performed to confirm previous findings. Furthermore, not only the optimal serum $25(\mathrm{OH}) \mathrm{D}$ level for the definition of vitamin $\mathrm{D}$ deficiency but also the relevant functional outcomes for bone and other health aspects need determination and validation so as to assess vitamin D status across the life cycle.

Supplementary Materials: The following are available online at https:/ / www.mdpi.com/1422-006 7/22/4/2128/s1.

Author Contributions: Writing—original draft preparation, S.Z.; writing-review and editing, D.D.M. and W.L.; supervision, W.L.; funding acquisition, W.L. All authors have read and agreed to the published version of the manuscript. 
Funding: This work was partially supported by NIH grant 1R01CA193609-01A1 to W.L. Its contents are solely the responsibility of the authors and do not necessarily represent the official views of the NIH. Additional support was provided by the University of Tennessee College of Pharmacy Drug Discovery Center to W.L.

Conflicts of Interest: The authors declare no conflict of interest.

\section{Abbreviations}

\begin{tabular}{|c|c|}
\hline $1 \alpha, 25(\mathrm{OH})_{2} \mathrm{D}$ & $1 \alpha, 25$-dihydroxyvitamin D \\
\hline $25(\mathrm{OH}) \mathrm{D}$ & 25-hydroxyvitamin D \\
\hline $\mathrm{APC}$ & antigen-presenting cell \\
\hline ARDS & acute respiratory distress syndrome \\
\hline BMI & body mass index \\
\hline CYP & cytochrome P450 \\
\hline CYP27B1 & cytochrome P450 27B1 \\
\hline CD & Crohn's disease \\
\hline $\mathrm{CHD}$ & coronary heart disease \\
\hline CVD & cardiovascular disease \\
\hline DC & dendritic cell \\
\hline DBP & vitamin $\mathrm{D}$ binding protein \\
\hline DU & Dobson unit \\
\hline HPLC & high performance liquid chromatography \\
\hline IBD & inflammatory bowel disease \\
\hline IL & interleukin \\
\hline IFN & interferon \\
\hline IU & international unit \\
\hline$M t b$ & Mycobacterium tuberculosis \\
\hline MS & multiple sclerosis \\
\hline NOX & reduced nicotinamide adenine dinucleotide phosphate oxidase \\
\hline PBMC & peripheral blood mononuclear cell \\
\hline PTH & parathyroid hormone \\
\hline RA & rheumatoid arthritis \\
\hline RANKL & receptor activator of nuclear factor- $\mathrm{k}$ B ligand \\
\hline $\mathrm{RCT}$ & randomized controlled trial \\
\hline RXR & retinoid- $X$ receptor \\
\hline ROS & reactive oxygen species \\
\hline RNS & reactive nitrogen species \\
\hline SLE & systemic lupus erythematosus \\
\hline SZA & solar zenith angle \\
\hline Th1 & T helper 1 \\
\hline TLR & toll-like receptor \\
\hline TNF & tumor necrosis factor \\
\hline Treg & $\mathrm{T}$ regulatory cell \\
\hline T1D & type 1 diabetes \\
\hline UVB & ultraviolet B \\
\hline UC & ulcerative colitis \\
\hline VDR & vitamin $\mathrm{D}$ receptor \\
\hline VDRE & vitamin D response element \\
\hline
\end{tabular}

\section{References}

1. Rajakumar, K. Vitamin D, cod-liver oil, sunlight, and rickets: A historical perspective. Pediatrics 2003, 112, e132-e135. [CrossRef] [PubMed]

2. Chesney, R.W. Rickets: An old form for a new century. Pediatrics Int. 2003, 45, 509-511. [CrossRef] [PubMed]

3. Holick, M.F.; Shils, M.; Shike, M.; Ross, A.; Caballero, B.; Cousins, R. Modern nutrition in health and disease. Shils OJME 2006, 329-345.

4. Hess, A.F. Rickets Including Osteomalacia and Tetany; Henty Kimpton: London, UK, 1930.

5. Nair, R.; Maseeh, A. Vitamin D: The "sunshine" vitamin. J. Pharmacol. Pharmacother. 2012, 3, 118-126. [PubMed] 
6. Holick, M.F.; Chen, T.C. Vitamin D deficiency: A worldwide problem with health consequences. Am. J. Clin. Nutr. 2008, 87, 1080S-1086S. [CrossRef] [PubMed]

7. MacLaughlin, J.A.; Anderson, R.R.; Holick, M.F. Spectral character of sunlight modulates photosynthesis of previtamin D3 and its photoisomers in human skin. Science 1982, 216, 1001-1003. [CrossRef]

8. Gupta, R.P.; Hollis, B.W.; Patel, S.B.; Patrick, K.S.; Bell, N.H. CYP3A4 is a human microsomal vitamin D 25-hydroxylase. J. Bone Miner. Res. 2004, 19, 680-688. [CrossRef]

9. Zhu, J.G.; Ochalek, J.T.; Kaufmann, M.; Jones, G.; Deluca, H.F. CYP2R1 is a major, but not exclusive, contributor to 25hydroxyvitamin D production in vivo. Proc. Natl. Acad. Sci. USA 2013, 110, 15650-15655. [CrossRef]

10. Yamasaki, T.; Izumi, S.; Ide, H.; Ohyama, Y. Identification of a novel rat microsomal vitamin D3 25-hydroxylase. J. Biol. Chem. 2004, 279, 22848-22856. [CrossRef]

11. Bosse, Y.; Lemire, M.; Poon, A.H.; Daley, D.; He, J.Q.; Sandford, A.; White, J.H.; James, A.L.; Musk, A.W.; Palmer, L.J.; et al. Asthma and genes encoding components of the vitamin D pathway. Respir. Res. 2009, 10, 98. [CrossRef]

12. Brunette, M.G.; Chan, M.; Ferriere, C.; Roberts, K.D. Site of 1,25(OH)2 vitamin D3 synthesis in the kidney. Nature 1978, 276, 287-289. [CrossRef] [PubMed]

13. Deeb, K.K.; Trump, D.L.; Johnson, C.S. Vitamin D signalling pathways in cancer: Potential for anticancer therapeutics. Nat. Rev. Cancer 2007, 7, 684-700. [CrossRef]

14. Slominski, A.; Semak, I.; Zjawiony, J.; Wortsman, J.; Li, W.; Szczesniewski, A.; Tuckey, R.C. The cytochrome P450scc system opens an alternate pathway of vitamin D3 metabolism. FEBS J. 2005, 272, 4080-4090. [CrossRef]

15. Slominski, A.; Semak, I.; Wortsman, J.; Zjawiony, J.; Li, W.; Zbytek, B.; Tuckey, R.C. An alternative pathway of vitamin D metabolism. Cytochrome P450scc (CYP11A1)-mediated conversion to 20-hydroxyvitamin D2 and 17,20-dihydroxyvitamin D2. FEBS J. 2006, 273, 2891-2901. [CrossRef]

16. Tuckey, R.C.; Li, W.; Zjawiony, J.K.; Zmijewski, M.A.; Nguyen, M.N.; Sweatman, T.; Miller, D.; Slominski, A. Pathways and products for the metabolism of vitamin D3 by cytochrome P450scc. FEBS J. 2008, 275, 2585-2596. [CrossRef]

17. Tuckey, R.C.; Li, W.; Shehabi, H.Z.; Janjetovic, Z.; Nguyen, M.N.; Kim, T.K.; Chen, J.; Howell, D.E.; Benson, H.A.; Sweatman, T.; et al. Production of 22-hydroxy metabolites of vitamin d3 by cytochrome p450scc (CYP11A1) and analysis of their biological activities on skin cells. Drug Metab. Dispos. 2011, 39, 1577-1588. [CrossRef] [PubMed]

18. Lin, Z.; Marepally, S.R.; Ma, D.; Kim, T.K.; Oak, A.S.; Myers, L.K.; Tuckey, R.C.; Slominski, A.T.; Miller, D.D.; Li, W. Synthesis and Biological Evaluation of Vitamin D3 Metabolite 20S,23S-Dihydroxyvitamin D3 and Its 23R Epimer. J. Med. Chem. 2016, 59, 5102-5108. [CrossRef] [PubMed]

19. Lin, Z.; Marepally, S.R.; Ma, D.; Myers, L.K.; Postlethwaite, A.E.; Tuckey, R.C.; Cheng, C.Y.; Kim, T.K.; Yue, J.; Slominski, A.T.; et al. Chemical Synthesis and Biological Activities of 20S,24S/R-Dihydroxyvitamin D3 Epimers and Their 1alpha-Hydroxyl Derivatives. J. Med. Chem. 2015, 58, 7881-7887. [CrossRef]

20. Zbytek, B.; Janjetovic, Z.; Tuckey, R.C.; Zmijewski, M.A.; Sweatman, T.W.; Jones, E.; Nguyen, M.N.; Slominski, A.T. 20Hydroxyvitamin D3, a product of vitamin D3 hydroxylation by cytochrome P450scc, stimulates keratinocyte differentiation. J. Investig. Dermatol. 2008, 128, 2271-2280. [CrossRef]

21. Li, W.; Chen, J.; Janjetovic, Z.; Kim, T.K.; Sweatman, T.; Lu, Y.; Zjawiony, J.; Tuckey, R.C.; Miller, D.; Slominski, A. Chemical synthesis of 20S-hydroxyvitamin D3, which shows antiproliferative activity. Steroids 2010, 75, 926-935. [CrossRef]

22. Wierzbicka, J.M.; Binek, A.; Ahrends, T.; Nowacka, J.D.; Szydlowska, A.; Turczyk, L.; Wasiewicz, T.; Wierzbicki, P.M.; Sadej, R.; Tuckey, R.C.; et al. Differential antitumor effects of vitamin D analogues on colorectal carcinoma in culture. Int. J. Oncol. 2015, 47, 1084-1096. [CrossRef]

23. Wasiewicz, T.; Szyszka, P.; Cichorek, M.; Janjetovic, Z.; Tuckey, R.C.; Slominski, A.T.; Zmijewski, M.A. Antitumor effects of vitamin D analogs on hamster and mouse melanoma cell lines in relation to melanin pigmentation. Int. J. Mol. Sci. 2015, 16, 6645-6667. [CrossRef]

24. Slominski, A.T.; Janjetovic, Z.; Fuller, B.E.; Zmijewski, M.A.; Tuckey, R.C.; Nguyen, M.N.; Sweatman, T.; Li, W.; Zjawiony, J.; Miller, D.; et al. Products of vitamin D3 or 7-dehydrocholesterol metabolism by cytochrome P450scc show anti-leukemia effects, having low or absent calcemic activity. PLoS ONE 2010, 5, e9907. [CrossRef]

25. Wang, J.; Slominski, A.; Tuckey, R.C.; Janjetovic, Z.; Kulkarni, A.; Chen, J.; Postlethwaite, A.E.; Miller, D.; Li, W. 20-hydroxyvitamin $\mathrm{D}(3)$ inhibits proliferation of cancer cells with high efficacy while being non-toxic. Anticancer Res. 2012, 32, 739-746. [PubMed]

26. Slominski, A.T.; Janjetovic, Z.; Kim, T.K.; Wright, A.C.; Grese, L.N.; Riney, S.J.; Nguyen, M.N.; Tuckey, R.C. Novel vitamin D hydroxyderivatives inhibit melanoma growth and show differential effects on normal melanocytes. Anticancer Res. 2012, 32, 3733-3742. [PubMed]

27. Slominski, A.T.; Janjetovic, Z.; Kim, T.K.; Wasilewski, P.; Rosas, S.; Hanna, S.; Sayre, R.M.; Dowdy, J.C.; Li, W.; Tuckey, R.C. Novel non-calcemic secosteroids that are produced by human epidermal keratinocytes protect against solar radiation. J. Steroid Biochem. Mol. Biol. 2015, 148, 52-63. [CrossRef] [PubMed]

28. Tongkao-On, W.; Carter, S.; Reeve, V.E.; Dixon, K.M.; Gordon-Thomson, C.; Halliday, G.M.; Tuckey, R.C.; Mason, R.S. CYP11A1 in skin: An alternative route to photoprotection by vitamin D compounds. J. Steroid Biochem. Mol. Biol. 2015, 148, 72-78. [CrossRef]

29. Slominski, A.T.; Kim, T.K.; Shehabi, H.Z.; Tang, E.K.; Benson, H.A.; Semak, I.; Lin, Z.; Yates, C.R.; Wang, J.; Li, W.; et al. In vivo production of novel vitamin D2 hydroxy-derivatives by human placentas, epidermal keratinocytes, Caco-2 colon cells and the adrenal gland. Mol. Cell. Endocrinol. 2014, 383, 181-192. [CrossRef] 
30. Slominski, A.T.; Kim, T.K.; Janjetovic, Z.; Tuckey, R.C.; Bieniek, R.; Yue, J.; Li, W.; Chen, J.; Nguyen, M.N.; Tang, E.K.; et al. 20-Hydroxyvitamin D2 is a noncalcemic analog of vitamin D with potent antiproliferative and prodifferentiation activities in normal and malignant cells. Am. J. Physiol. Cell Physiol. 2011, 300, C526-C541. [CrossRef]

31. Slominski, A.; Janjetovic, Z.; Tuckey, R.C.; Nguyen, M.N.; Bhattacharya, K.G.; Wang, J.; Li, W.; Jiao, Y.; Gu, W.; Brown, M.; et al. 20S-hydroxyvitamin D3, noncalcemic product of CYP11A1 action on vitamin D3, exhibits potent antifibrogenic activity in vivo. J. Clin. Endocrinol. Metab. 2013, 98, E298-E303. [CrossRef]

32. Binkley, N.; Novotny, R.; Krueger, D.; Kawahara, T.; Daida, Y.G.; Lensmeyer, G.; Hollis, B.W.; Drezner, M.K. Low vitamin D status despite abundant sun exposure. J. Clin. Endocrinol. Metab. 2007, 92, 2130-2135. [CrossRef]

33. Armas, L.A.; Hollis, B.W.; Heaney, R.P. Vitamin D2 is much less effective than vitamin D3 in humans. J. Clin. Endocrinol. Metab. 2004, 89, 5387-5391. [CrossRef] [PubMed]

34. Romagnoli, E.; Mascia, M.L.; Cipriani, C.; Fassino, V.; Mazzei, F.; D’Erasmo, E.; Carnevale, V.; Scillitani, A.; Minisola, S. Short and long-term variations in serum calciotropic hormones after a single very large dose of ergocalciferol (vitamin D2) or cholecalciferol (vitamin D3) in the elderly. J. Clin. Endocrinol. Metab. 2008, 93, 3015-3020. [CrossRef] [PubMed]

35. Holick, M.F.; Biancuzzo, R.M.; Chen, T.C.; Klein, E.K.; Young, A.; Bibuld, D.; Reitz, R.; Salameh, W.; Ameri, A.; Tannenbaum, A.D. Vitamin D2 is as effective as vitamin D3 in maintaining circulating concentrations of 25-hydroxyvitamin D. J. Clin. Endocrinol. Metab. 2008, 93, 677-681. [CrossRef]

36. Biancuzzo, R.M.; Young, A.; Bibuld, D.; Cai, M.H.; Winter, M.R.; Klein, E.K.; Ameri, A.; Reitz, R.; Salameh, W.; Chen, T.C.; et al. Fortification of orange juice with vitamin $\mathrm{D}(2)$ or vitamin $\mathrm{D}(3)$ is as effective as an oral supplement in maintaining vitamin $\mathrm{D}$ status in adults. Am. J. Clin. Nutr. 2010, 91, 1621-1626. [CrossRef]

37. Markestad, T.; Halvorsen, S.; Halvorsen, K.S.; Aksnes, L.; Aarskog, D. Plasma concentrations of vitamin D metabolites before and during treatment of vitamin D deficiency rickets in children. Acta Paediatr. Scand 1984, 73, 225-231. [CrossRef] [PubMed]

38. Holick, M.F. High prevalence of vitamin D inadequacy and implications for health. Mayo Clin. Proc. 2006, 81, 353-373. [CrossRef]

39. DeLuca, H.F. Evolution of our understanding of vitamin D. Nutr. Rev. 2008, 66, S73-S87. [CrossRef]

40. Bikle, D. Nonclassic actions of vitamin D. J. Clin. Endocrinol. Metab. 2009, 94, 26-34. [CrossRef]

41. Heijboer, A.C.; Blankenstein, M.A.; Kema, I.P.; Buijs, M.M. Accuracy of 6 routine 25-hydroxyvitamin D assays: Influence of vitamin D binding protein concentration. Clin. Chem. 2012, 58, 543-548. [CrossRef]

42. Passeron, T.; Bouillon, R.; Callender, V.; Cestari, T.; Diepgen, T.L.; Green, A.C.; van der Pols, J.C.; Bernard, B.A.; Ly, F.; Bernerd, F.; et al. Sunscreen photoprotection and vitamin D status. Br. J. Dermatol. 2019, 181, 916-931. [CrossRef]

43. Malabanan, A.; Veronikis, I.E.; Holick, M.F. Redefining vitamin D insufficiency. Lancet 1998, 351, 805-806. [CrossRef]

44. Wagner, C.L.; Greer, F.R.; Section on Breastfeeding and Committee on Nutrition. Prevention of rickets and vitamin D deficiency in infants, children, and adolescents. Pediatrics 2008, 122, 1142-1152. [CrossRef] [PubMed]

45. Tsiaras, W.G.; Weinstock, M.A. Factors influencing vitamin D status. Acta Derm. Venereol. 2011, 91, 115-124. [CrossRef]

46. Holick, M.F. Resurrection of vitamin D deficiency and rickets. J. Clin. Investig. 2006, 116, 2062-2072. [CrossRef] [PubMed]

47. Holick, M.F. Phylogenetic and evolutionary aspects of vitamin D from phytoplankton to humans. In Vertebrate Endocrinology: Fundamentals and Biomedical Implications; Pang, P., Schreibman, M., Eds.; Academic Press: Orlando, FL, USA, 1989; Volume 3, pp. $7-43$.

48. Norval, M.; Bjorn, L.O.; de Gruijl, F.R. Is the action spectrum for the UV-induced production of previtamin D3 in human skin correct? Photochem. Photobiol. Sci. 2010, 9, 11-17. [CrossRef] [PubMed]

49. Kimlin, M.G. Geographic location and vitamin D synthesis. Mol. Asp. Med. 2008, 29, 453-461. [CrossRef] [PubMed]

50. Engelsen, O.; Brustad, M.; Aksnes, L.; Lund, E. Daily duration of vitamin D synthesis in human skin with relation to latitude, total ozone, altitude, ground cover, aerosols and cloud thickness. Photochem. Photobiol. 2005, 81, 1287-1290. [CrossRef] [PubMed]

51. Highwood, E.J.; Kinnersley, R.P. When smoke gets in our eyes: The multiple impacts of atmospheric black carbon on climate, air quality and health. Environ. Int. 2006, 32, 560-566. [CrossRef] [PubMed]

52. Mims, F.M., 3rd. Significant reduction of UVB caused by smoke from biomass burning in Brazil. Photochem. Photobiol. 1996, 64, 814-816.

53. Webb, A.R.; Engelsen, O. Ultraviolet exposure scenarios: Risks of erythema from recommendations on cutaneous vitamin D synthesis. Adv. Exp. Med. Biol. 2008, 624, 72-85. [PubMed]

54. Holick, M.F. Vitamin D: A millenium perspective. J. Cell. Biochem. 2003, 88, 296-307. [CrossRef]

55. Webb, A.R.; Kline, L.; Holick, M.F. Influence of season and latitude on the cutaneous synthesis of vitamin D3: Exposure to winter sunlight in Boston and Edmonton will not promote vitamin D3 synthesis in human skin. J. Clin. Endocrinol. Metab. 1988, 67, 373-378. [CrossRef]

56. Sampat, N.; Al-Balushi, B.; Al-Subhi, L.; Al-Adawi, S.; Essa, M.M.; Qoronfleh, M.W. Vitamin D: Public Health Status Regional Gulf Region. Int. J. Nutr. Pharmacol. Neurol. Dis. 2019, 9, 117-135.

57. Nesby-O'Dell, S.; Scanlon, K.S.; Cogswell, M.E.; Gillespie, C.; Hollis, B.W.; Looker, A.C.; Allen, C.; Doughertly, C.; Gunter, E.W.; Bowman, B.A. Hypovitaminosis D prevalence and determinants among African American and white women of reproductive age: Third National Health and Nutrition Examination Survey, 1988-1994. Am. J. Clin. Nutr. 2002, 76, 187-192. [CrossRef]

58. Webb, A.R.; Kazantzidis, A.; Kift, R.C.; Farrar, M.D.; Wilkinson, J.; Rhodes, L.E. Colour Counts: Sunlight and Skin Type as Drivers of Vitamin D Deficiency at UK Latitudes. Nutrients 2018, 10, 457. [CrossRef] [PubMed] 
59. Marwaha, R.K.; Sreenivas, V.; Talwar, D.; Yenamandra, V.K.; Challa, A.; Lakshmy, R.; Sharma, V.K.; Sethuraman, G. Impact of solar ultraviolet B radiation $(290-320 \mathrm{~nm})$ on vitamin D synthesis in children with type IV and V skin. Br. J. Dermatol. 2015, 173, 604-606. [CrossRef] [PubMed]

60. Cashman, K.D.; van den Heuvel, E.G.; Schoemaker, R.J.; Preveraud, D.P.; Macdonald, H.M.; Arcot, J. 25-Hydroxyvitamin D as a Biomarker of Vitamin D Status and Its Modeling to Inform Strategies for Prevention of Vitamin D Deficiency within the Population. Adv. Nutr. 2017, 8, 947-957. [CrossRef] [PubMed]

61. Slominski, A.; Postlethwaite, A.E. Skin under the sun: When melanin pigment meets vitamin D. Endocrinology 2015, 156, 1-4. [CrossRef]

62. Bogh, M.K.; Schmedes, A.V.; Philipsen, P.A.; Thieden, E.; Wulf, H.C. Vitamin D production after UVB exposure depends on baseline vitamin D and total cholesterol but not on skin pigmentation. J. Investig. Dermatol. 2010, 130, 546-553. [CrossRef]

63. Xiang, F.; Lucas, R.; de Gruijl, F.; Norval, M. A systematic review of the influence of skin pigmentation on changes in the concentrations of vitamin D and 25-hydroxyvitamin D in plasma/serum following experimental UV irradiation. Photochem. Photobiol. Sci. 2015, 14, 2138-2146. [CrossRef]

64. Young, A.R.; Morgan, K.A.; Ho, T.W.; Ojimba, N.; Harrison, G.I.; Lawrence, K.P.; Jakharia-Shah, N.; Wulf, H.C.; Cruickshank, J.K.; Philipsen, P.A. Melanin has a Small Inhibitory Effect on Cutaneous Vitamin D Synthesis: A Comparison of Extreme Phenotypes. J. Investig. Dermatol. 2020, 140, 1418-1426.e1. [CrossRef]

65. Matsuoka, L.Y.; Wortsman, J.; Hollis, B.W. Use of topical sunscreen for the evaluation of regional synthesis of vitamin D3. J. Am. Acad. Dermatol. 1990, 22, 772-775. [CrossRef]

66. Matsuoka, L.Y.; Ide, L.; Wortsman, J.; MacLaughlin, J.A.; Holick, M.F. Sunscreens suppress cutaneous vitamin D3 synthesis. J. Clin. Endocrinol. Metab. 1987, 64, 1165-1168. [CrossRef] [PubMed]

67. Libon, F.; Courtois, J.; Le Goff, C.; Lukas, P.; Fabregat-Cabello, N.; Seidel, L.; Cavalier, E.; Nikkels, A.F. Sunscreens block cutaneous vitamin D production with only a minimal effect on circulating 25-hydroxyvitamin D. Arch. Osteoporos. 2017, 12, 66. [CrossRef]

68. Faurschou, A.; Beyer, D.M.; Schmedes, A.; Bogh, M.K.; Philipsen, P.A.; Wulf, H.C. The relation between sunscreen layer thickness and vitamin D production after ultraviolet B exposure: A randomized clinical trial. Br. J. Dermatol. 2012, 167, 391-395. [CrossRef] [PubMed]

69. Young, A.R.; Narbutt, J.; Harrison, G.I.; Lawrence, K.P.; Bell, M.; O’Connor, C.; Olsen, P.; Grys, K.; Baczynska, K.A.; RogowskiTylman, M.; et al. Optimal sunscreen use, during a sun holiday with a very high ultraviolet index, allows vitamin D synthesis without sunburn. Br. J. Dermatol. 2019, 181, 1052-1062. [CrossRef]

70. Klein, G.L.; Chen, T.C.; Holick, M.F.; Langman, C.B.; Price, H.; Celis, M.M.; Herndon, D.N. Synthesis of vitamin D in skin after burns. Lancet 2004, 363, 291-292. [CrossRef]

71. MacLaughlin, J.; Holick, M.F. Aging decreases the capacity of human skin to produce vitamin D3. J. Clin. Investig. 1985, 76, 1536-1538. [CrossRef]

72. Lo, C.W.; Paris, P.W.; Clemens, T.L.; Nolan, J.; Holick, M.F. Vitamin D absorption in healthy subjects and in patients with intestinal malabsorption syndromes. Am. J. Clin. Nutr. 1985, 42, 644-649. [CrossRef]

73. Dueland, S.; Pedersen, J.I.; Helgerud, P.; Drevon, C.A. Absorption, distribution, and transport of vitamin D3 and 25hydroxyvitamin D3 in the rat. Am. J. Physiol. 1983, 245, E463-E467. [CrossRef]

74. Haddad, J.G.; Matsuoka, L.Y.; Hollis, B.W.; Hu, Y.Z.; Wortsman, J. Human plasma transport of vitamin D after its endogenous synthesis. J. Clin. Investig. 1993, 91, 2552-2555. [CrossRef]

75. Blum, M.; Dolnikowski, G.; Seyoum, E.; Harris, S.S.; Booth, S.L.; Peterson, J.; Saltzman, E.; Dawson-Hughes, B. Vitamin D(3) in fat tissue. Endocrine 2008, 33, 90-94. [CrossRef]

76. Hyldstrup, L.; Andersen, T.; McNair, P.; Breum, L.; Transbol, I. Bone metabolism in obesity: Changes related to severe overweight and dietary weight reduction. Acta Endocrinol. 1993, 129, 393-398. [CrossRef]

77. Liel, Y.; Ulmer, E.; Shary, J.; Hollis, B.W.; Bell, N.H. Low circulating vitamin D in obesity. Calcif. Tissue Int. 1988, 43, 199-201. [CrossRef]

78. Bell, N.H.; Epstein, S.; Greene, A.; Shary, J.; Oexmann, M.J.; Shaw, S. Evidence for alteration of the vitamin D-endocrine system in obese subjects. J. Clin. Investig. 1985, 76, 370-373. [CrossRef] [PubMed]

79. Wortsman, J.; Matsuoka, L.Y.; Chen, T.C.; Lu, Z.; Holick, M.F. Decreased bioavailability of vitamin D in obesity. Am. J. Clin. Nutr. 2000, 72, 690-693. [CrossRef] [PubMed]

80. Holick, M.F. Vitamin D deficiency. N. Engl. J. Med. 2007, 357, 266-281. [CrossRef] [PubMed]

81. Zhou, C.; Assem, M.; Tay, J.C.; Watkins, P.B.; Blumberg, B.; Schuetz, E.G.; Thummel, K.E. Steroid and xenobiotic receptor and vitamin D receptor crosstalk mediates CYP24 expression and drug-induced osteomalacia. J. Clin. Investig. 2006, 116, 1703-1712. [CrossRef]

82. DeLuca, H.F. Overview of general physiologic features and functions of vitamin D. Am. J. Clin. Nutr. 2004, 80, 1689S-1696S. [CrossRef]

83. Prie, D.; Beck, L.; Urena, P.; Friedlander, G. Recent findings in phosphate homeostasis. Curr. Opin. Nephrol. Hypertens. 2005, 14, 318-324. [CrossRef]

84. Tonelli, M.; Sacks, F.; Pfeffer, M.; Gao, Z.; Curhan, G. Relation between serum phosphate level and cardiovascular event rate in people with coronary disease. Circulation 2005, 112, 2627-2633. [CrossRef] [PubMed] 
85. Urena Torres, P.; Friedlander, G.; de Vernejoul, M.C.; Silve, C.; Prie, D. Bone mass does not correlate with the serum fibroblast growth factor 23 in hemodialysis patients. Kidney Int. 2008, 73, 102-107. [CrossRef] [PubMed]

86. Pappa, H.M.; Bern, E.; Kamin, D.; Grand, R.J. Vitamin D status in gastrointestinal and liver disease. Curr. Opin. Gastroenterol. 2008, 24, 176-183. [CrossRef] [PubMed]

87. Heubi, J.E.; Hollis, B.W.; Specker, B.; Tsang, R.C. Bone disease in chronic childhood cholestasis. I. Vitamin D absorption and metabolism. Hepatology 1989, 9, 258-264. [CrossRef] [PubMed]

88. Fisher, L.; Fisher, A. Vitamin D and parathyroid hormone in outpatients with noncholestatic chronic liver disease. Clin. Gastroenterol. Hepatol. 2007, 5, 513-520. [CrossRef]

89. Gallieni, M.; Cozzolino, M.; Fallabrino, G.; Pasho, S.; Olivi, L.; Brancaccio, D. Vitamin D: Physiology and pathophysiology. Int. J. Artif. Organs 2009, 32, 87-94. [CrossRef]

90. Speeckaert, M.; Huang, G.; Delanghe, J.R.; Taes, Y.E. Biological and clinical aspects of the vitamin D binding protein (Gc-globulin) and its polymorphism. Clin. Chim. Acta 2006, 372, 33-42. [CrossRef] [PubMed]

91. Gal-Moscovici, A.; Sprague, S.M. Role of vitamin D deficiency in chronic kidney disease. J. Bone Miner. Res. 2007, 22 (Suppl. 2), V91-V94. [CrossRef]

92. Pitts, T.O.; Piraino, B.H.; Mitro, R.; Chen, T.C.; Segre, G.V.; Greenberg, A.; Puschett, J.B. Hyperparathyroidism and 1,25dihydroxyvitamin D deficiency in mild, moderate, and severe renal failure. J. Clin. Endocrinol. Metab. 1988, 67, 876-881. [CrossRef] [PubMed]

93. Reichel, H.; Deibert, B.; Schmidt-Gayk, H.; Ritz, E. Calcium metabolism in early chronic renal failure: Implications for the pathogenesis of hyperparathyroidism. Nephrol. Dial. Transplant. 1991, 6, 162-169. [CrossRef]

94. National Kidney, F. K/DOQI clinical practice guidelines for bone metabolism and disease in chronic kidney disease. Am. J. Kidney Dis. 2003, 42, S1-S201.

95. Holick, M.F. Vitamin D for health and in chronic kidney disease. Semin. Dial. 2005, 18, 266-275. [CrossRef]

96. Christakos, S.; Dhawan, P.; Verstuyf, A.; Verlinden, L.; Carmeliet, G. Vitamin D: Metabolism, Molecular Mechanism of Action, and Pleiotropic Effects. Physiol. Rev. 2016, 96, 365-408. [CrossRef]

97. Christakos, S.; Dhawan, P.; Liu, Y.; Peng, X.; Porta, A. New insights into the mechanisms of vitamin D action. J. Cell. Biochem. 2003, 88, 695-705. [CrossRef] [PubMed]

98. Holick, M.F. Vitamin D: Importance in the prevention of cancers, type 1 diabetes, heart disease, and osteoporosis. Am. J. Clin. Nutr. 2004, 79, 362-371. [CrossRef]

99. Boullion, R. Vitamin D: From photosynthesis, metabolism, and action to clinical application. In Endocrinology; Elsevier Saunders: Philadelphia, PA, USA, 2006; pp. 1435-1463.

100. Brown, E.M.; Gamba, G.; Riccardi, D.; Lombardi, M.; Butters, R.; Kifor, O.; Sun, A.; Hediger, M.A.; Lytton, J.; Hebert, S.C. Cloning and characterization of an extracellular $\mathrm{Ca}(2+)$-sensing receptor from bovine parathyroid. Nature 1993, 366, 575-580. [CrossRef] [PubMed]

101. Khosla, S. Minireview: The OPG/RANKL/RANK system. Endocrinology 2001, 142, 5050-5055. [CrossRef] [PubMed]

102. Unuvar, T.; Buyukgebiz, A. Nutritional rickets and vitamin D deficiency in infants, children and adolescents. Pediatric Endocrinol. Rev. 2010, 7, 283-291.

103. Fink, C.; Peters, R.L.; Koplin, J.J.; Brown, J.; Allen, K.J. Factors Affecting Vitamin D Status in Infants. Children 2019, 6, 7. [CrossRef]

104. Dawodu, A.; Tsang, R.C. Maternal vitamin D status: Effect on milk vitamin D content and vitamin D status of breastfeeding infants. Adv. Nutr. 2012, 3, 353-361. [CrossRef] [PubMed]

105. vieth Streym, S.; Hojskov, C.S.; Moller, U.K.; Heickendorff, L.; Vestergaard, P.; Mosekilde, L.; Rejnmark, L. Vitamin D content in human breast milk: A 9-mo follow-up study. Am. J. Clin. Nutr. 2016, 103, 107-114. [CrossRef] [PubMed]

106. Hollis, B.W.; Wagner, C.L.; Howard, C.R.; Ebeling, M.; Shary, J.R.; Smith, P.G.; Taylor, S.N.; Morella, K.; Lawrence, R.A.; Hulsey, T.C. Maternal Versus Infant Vitamin D Supplementation During Lactation: A Randomized Controlled Trial. Pediatrics 2015, 136, 625-634. [CrossRef] [PubMed]

107. Basile, L.A.; Taylor, S.N.; Wagner, C.L.; Horst, R.L.; Hollis, B.W. The effect of high-dose vitamin D supplementation on serum vitamin D levels and milk calcium concentration in lactating women and their infants. Breastfeed. Med. 2006, 1, 27-35. [CrossRef] [PubMed]

108. Naik, P.; Faridi, M.M.A.; Batra, P.; Madhu, S.V. Oral Supplementation of Parturient Mothers with Vitamin D and Its Effect on 25OHD Status of Exclusively Breastfed Infants at 6 Months of Age: A Double-Blind Randomized Placebo Controlled Trial. Breastfeed. Med. 2017, 12, 621-628. [CrossRef]

109. Wheeler, B.J.; Taylor, B.J.; Herbison, P.; Haszard, J.J.; Mikhail, A.; Jones, S.; Harper, M.J.; Houghton, L.A. High-Dose Monthly Maternal Cholecalciferol Supplementation during Breastfeeding Affects Maternal and Infant Vitamin D Status at 5 Months Postpartum: A Randomized Controlled Trial. J. Nutr. 2016, 146, 1999-2006. [CrossRef] [PubMed]

110. Ross, A.C.; Taylor, C.L.; Yaktine, A.L.; Del Valle, H.B. (Eds.) Dietary Reference Intakes for Calcium and Vitamin D; The National Academies Press: Washington, DC, USA, 2011.

111. Writing Group on Osteoporosis for the British Menopause Society Council; Al-Azzawi, F.; Barlow, D.; Hillard, T.; Studd, J.; Williamson, J.; Rees, M. Prevention and treatment of osteoporosis in women. Menopause Int. 2007, 13, $178-181$.

112. Malavolta, N.; Pratelli, L.; Frigato, M.; Mule, R.; Mascia, M.L.; Gnudi, S. The relationship of vitamin D status to bone mineral density in an Italian population of postmenopausal women. Osteoporos. Int. 2005, 16, 1691-1697. [CrossRef] 
113. Gallacher, S.J.; McQuillian, C.; Harkness, M.; Finlay, F.; Gallagher, A.P.; Dixon, T. Prevalence of vitamin D inadequacy in Scottish adults with non-vertebral fragility fractures. Curr. Med. Res. Opin. 2005, 21, 1355-1361. [CrossRef]

114. Simonelli, C.; Weiss, T.W.; Morancey, J.; Swanson, L.; Chen, Y.T. Prevalence of vitamin D inadequacy in a minimal trauma fracture population. Curr. Med. Res. Opin. 2005, 21, 1069-1074. [CrossRef] [PubMed]

115. Brown, S.E. Vitamin D and fracture reduction: An evaluation of the existing research. Altern. Med. Rev. 2008, 13, 21-33. [PubMed]

116. Kanis, J.A. Diagnosis of osteoporosis and assessment of fracture risk. Lancet 2002, 359, 1929-1936. [CrossRef]

117. Dawson-Hughes, B.; Harris, S.S.; Krall, E.A.; Dallal, G.E. Effect of calcium and vitamin D supplementation on bone density in men and women 65 years of age or older. N. Engl. J. Med. 1997, 337, 670-676. [CrossRef] [PubMed]

118. Chapuy, M.C.; Arlot, M.E.; Duboeuf, F.; Brun, J.; Crouzet, B.; Arnaud, S.; Delmas, P.D.; Meunier, P.J. Vitamin D3 and calcium to prevent hip fractures in elderly women. N. Engl. J. Med. 1992, 327, 1637-1642. [CrossRef] [PubMed]

119. Geller, J.L.; Adams, J.S. Vitamin D therapy. Curr. Osteoporos. Rep. 2008, 6, 5-11. [CrossRef]

120. Montero-Odasso, M.; Duque, G. Vitamin D in the aging musculoskeletal system: An authentic strength preserving hormone. Mol. Aspects Med. 2005, 26, 203-219. [CrossRef]

121. Staud, R. Vitamin D: More than just affecting calcium and bone. Curr. Rheumatol. Rep. 2005, 7, 356-364. [CrossRef]

122. Ceglia, L. Vitamin D and skeletal muscle tissue and function. Mol. Aspects Med. 2008, 29, 407-414. [CrossRef]

123. Bischoff-Ferrari, H.A.; Giovannucci, E.; Willett, W.C.; Dietrich, T.; Dawson-Hughes, B. Estimation of optimal serum concentrations of 25-hydroxyvitamin D for multiple health outcomes. Am. J. Clin. Nutr. 2006, 84, 18-28. [CrossRef] [PubMed]

124. Gallagher, J.C. The effects of calcitriol on falls and fractures and physical performance tests. J. Steroid Biochem. Mol. Biol. 2004, 89-90, 497-501. [CrossRef]

125. Muir, S.W.; Montero-Odasso, M. Effect of vitamin D supplementation on muscle strength, gait and balance in older adults: A systematic review and meta-analysis. J. Am. Geriatr. Soc. 2011, 59, 2291-2300. [CrossRef]

126. Pramyothin, P.; Holick, M.F. Vitamin D supplementation: Guidelines and evidence for subclinical deficiency. Curr. Opin. Gastroenterol. 2012, 28, 139-150. [CrossRef]

127. Bischoff-Ferrari, H.A.; Shao, A.; Dawson-Hughes, B.; Hathcock, J.; Giovannucci, E.; Willett, W.C. Benefit-risk assessment of vitamin D supplementation. Osteoporos. Int. 2010, 21, 1121-1132. [CrossRef]

128. Pfeifer, M.; Begerow, B.; Minne, H.W.; Suppan, K.; Fahrleitner-Pammer, A.; Dobnig, H. Effects of a long-term vitamin D and calcium supplementation on falls and parameters of muscle function in community-dwelling older individuals. Osteoporos. Int. 2009, 20, 315-322. [CrossRef]

129. Chlebowski, R.T.; Johnson, K.C.; Kooperberg, C.; Pettinger, M.; Wactawski-Wende, J.; Rohan, T.; Rossouw, J.; Lane, D.; O'Sullivan, M.J.; Yasmeen, S.; et al. Calcium plus vitamin D supplementation and the risk of breast cancer. J. Natl. Cancer Inst. 2008, 100, 1581-1591. [CrossRef] [PubMed]

130. Wang, T.J.; Pencina, M.J.; Booth, S.L.; Jacques, P.F.; Ingelsson, E.; Lanier, K.; Benjamin, E.J.; D’Agostino, R.B.; Wolf, M.; Vasan, R.S. Vitamin D deficiency and risk of cardiovascular disease. Circulation 2008, 117, 503-511. [CrossRef] [PubMed]

131. Lips, P.; Hosking, D.; Lippuner, K.; Norquist, J.M.; Wehren, L.; Maalouf, G.; Ragi-Eis, S.; Chandler, J. The prevalence of vitamin D inadequacy amongst women with osteoporosis: An international epidemiological investigation. J. Intern. Med. 2006, 260, 245-254. [CrossRef]

132. Mora, J.R.; Iwata, M.; von Andrian, U.H. Vitamin effects on the immune system: Vitamins A and D take centre stage. Nat. Rev. Immunol. 2008, 8, 685-698. [CrossRef]

133. Lemire, J.M.; Adams, J.S.; Sakai, R.; Jordan, S.C. 1 alpha,25-dihydroxyvitamin D3 suppresses proliferation and immunoglobulin production by normal human peripheral blood mononuclear cells. J. Clin. Investig. 1984, 74, 657-661. [CrossRef] [PubMed]

134. Rigby, W.F.; Stacy, T.; Fanger, M.W. Inhibition of T lymphocyte mitogenesis by 1,25-dihydroxyvitamin D3 (calcitriol). J. Clin. Investig. 1984, 74, 1451-1455. [CrossRef]

135. Vaisberg, M.W.; Kaneno, R.; Franco, M.F.; Mendes, N.F. Influence of cholecalciferol (vitamin D3) on the course of experimental systemic lupus erythematosus in F1 (NZBxW) mice. J. Clin. Lab. Anal. 2000, 14, 91-96. [CrossRef]

136. Cantorna, M.T.; Mahon, B.D. Mounting evidence for vitamin D as an environmental factor affecting autoimmune disease prevalence. Exp. Biol. Med. 2004, 229, 1136-1142. [CrossRef]

137. Penna, G.; Adorini, L. 1 Alpha,25-dihydroxyvitamin D3 inhibits differentiation, maturation, activation, and survival of dendritic cells leading to impaired alloreactive T cell activation. J. Immunol. 2000, 164, 2405-2411. [CrossRef] [PubMed]

138. McCollum, E.V.; Pitz, W.; Simmonds, N.; Becker, J.E.; Shipley, P.G.; Bunting, R.W. The effect of additions of fluorine to the diet of the rat on the quality of the teeth. 1925. Studies on experimental rickets. XXI. An experimental demonstration of the existence of a vitamin which promotes calcium deposition. 1922. The effect of additions of fluorine to the diet of the rat on the quality of the teeth. 1925. J. Biol. Chem. 2002, 277, E8. [PubMed]

139. Canning, M.O.; Grotenhuis, K.; de Wit, H.; Ruwhof, C.; Drexhage, H.A. 1-alpha,25-Dihydroxyvitamin D3 (1,25(OH)(2)D(3)) hampers the maturation of fully active immature dendritic cells from monocytes. Eur. J. Endocrinol. 2001, 145, 351-357. [CrossRef]

140. Szekely, J.I.; Pataki, A. Effects of vitamin D on immune disorders with special regard to asthma, COPD and autoimmune diseases: A short review. Expert Rev. Respir. Med. 2012, 6, 683-704. [CrossRef]

141. Alroy, I.; Towers, T.L.; Freedman, L.P. Transcriptional repression of the interleukin-2 gene by vitamin D3: Direct inhibition of NFATp/AP-1 complex formation by a nuclear hormone receptor. Mol. Cell Biol. 1995, 15, 5789-5799. [CrossRef] 
142. Mahon, B.D.; Wittke, A.; Weaver, V.; Cantorna, M.T. The targets of vitamin D depend on the differentiation and activation status of CD4 positive T cells. J. Cell. Biochem. 2003, 89, 922-932. [CrossRef] [PubMed]

143. Boonstra, A.; Barrat, F.J.; Crain, C.; Heath, V.L.; Savelkoul, H.F.; O'Garra, A. 1alpha,25-Dihydroxyvitamin d3 has a direct effect on naive CD4(+) T cells to enhance the development of Th2 cells. J. Immunol. 2001, 167, 4974-4980. [CrossRef]

144. van Etten, E.; Mathieu, C. Immunoregulation by 1,25-dihydroxyvitamin D3: Basic concepts. J. Steroid Biochem. Mol. Biol. 2005, 97, 93-101. [CrossRef]

145. Chen, S.; Sims, G.P.; Chen, X.X.; Gu, Y.Y.; Chen, S.; Lipsky, P.E. Modulatory effects of 1,25-dihydroxyvitamin D3 on human B cell differentiation. J. Immunol. 2007, 179, 1634-1647. [CrossRef]

146. Davidson, A.; Diamond, B. Autoimmune diseases. N. Engl. J. Med. 2001, 345, 340-350. [CrossRef] [PubMed]

147. Pludowski, P.; Holick, M.F.; Pilz, S.; Wagner, C.L.; Hollis, B.W.; Grant, W.B.; Shoenfeld, Y.; Lerchbaum, E.; Llewellyn, D.J.; Kienreich, K.; et al. Vitamin D effects on musculoskeletal health, immunity, autoimmunity, cardiovascular disease, cancer, fertility, pregnancy, dementia and mortality-a review of recent evidence. Autoimmun. Rev. 2013, 12, 976-989. [CrossRef]

148. Kriegel, M.A.; Manson, J.E.; Costenbader, K.H. Does vitamin D affect risk of developing autoimmune disease?: A systematic review. Semin. Arthritis Rheum. 2011, 40, 512-531. [CrossRef] [PubMed]

149. Antico, A.; Tampoia, M.; Tozzoli, R.; Bizzaro, N. Can supplementation with vitamin D reduce the risk or modify the course of autoimmune diseases? A systematic review of the literature. Autoimmun. Rev. 2012, 12, 127-136. [CrossRef] [PubMed]

150. Cutolo, M.; Otsa, K.; Paolino, S.; Yprus, M.; Veldi, T.; Seriolo, B. Vitamin D involvement in rheumatoid arthritis and systemic lupus erythaematosus. Ann. Rheum. Dis. 2009, 68, 446-447. [CrossRef]

151. Sen, D.; Ranganathan, P. Vitamin D in rheumatoid arthritis: Panacea or placebo? Discov. Med. 2012, 14, 311-319. [PubMed]

152. Ponsonby, A.L.; McMichael, A.; van der Mei, I. Ultraviolet radiation and autoimmune disease: Insights from epidemiological research. Toxicology 2002, 181-182, 71-78. [CrossRef]

153. Sokka, T.; Pincus, T. Quantitative joint assessment in rheumatoid arthritis. Clin. Exp. Rheumatol. 2005, 23, S58-S62.

154. Zwerina, K.; Baum, W.; Axmann, R.; Heiland, G.R.; Distler, J.H.; Smolen, J.; Hayer, S.; Zwerina, J.; Schett, G. Vitamin D receptor regulates TNF-mediated arthritis. Ann. Rheum. Dis. 2011, 70, 1122-1129. [CrossRef] [PubMed]

155. Cantorna, M.T.; Hayes, C.E.; DeLuca, H.F. 1,25-Dihydroxycholecalciferol inhibits the progression of arthritis in murine models of human arthritis. J. Nutr. 1998, 128, 68-72. [CrossRef]

156. Lin, J.; Liu, J.; Davies, M.L.; Chen, W. Serum Vitamin D Level and Rheumatoid Arthritis Disease Activity: Review and MetaAnalysis. PLoS ONE 2016, 11, e0146351. [CrossRef]

157. Franco, A.S.; Freitas, T.Q.; Bernardo, W.M.; Pereira, R.M.R. Vitamin D supplementation and disease activity in patients with immune-mediated rheumatic diseases: A systematic review and meta-analysis. Medicine 2017, 96, e7024. [CrossRef]

158. de la Torre Lossa, P.; Moreno Alvarez, M.; Gonzalez Guzman, M.D.C.; Lopez Martinez, R.; Rios Acosta, C. Vitamin D is not useful as a biomarker for disease activity in rheumatoid arthritis. Reumatol. Clin. 2020, 16, 110-115. [CrossRef] [PubMed]

159. Meena, N.; Singh Chawla, S.P.; Garg, R.; Batta, A.; Kaur, S. Assessment of Vitamin D in Rheumatoid Arthritis and Its Correlation with Disease Activity. J. Nat. Sci. Biol. Med. 2018, 9, 54-58.

160. Xu, X.R.; Liu, C.Q.; Feng, B.S.; Liu, Z.J. Dysregulation of mucosal immune response in pathogenesis of inflammatory bowel disease. World J. Gastroenterol. 2014, 20, 3255-3264. [CrossRef]

161. Cantorna, M.T.; Munsick, C.; Bemiss, C.; Mahon, B.D. 1,25-Dihydroxycholecalciferol prevents and ameliorates symptoms of experimental murine inflammatory bowel disease. J. Nutr. 2000, 130, 2648-2652. [CrossRef] [PubMed]

162. Froicu, M.; Weaver, V.; Wynn, T.A.; McDowell, M.A.; Welsh, J.E.; Cantorna, M.T. A crucial role for the vitamin D receptor in experimental inflammatory bowel diseases. Mol. Endocrinol. 2003, 17, 2386-2392. [CrossRef]

163. Jorgensen, S.P.; Agnholt, J.; Glerup, H.; Lyhne, S.; Villadsen, G.E.; Hvas, C.L.; Bartels, L.E.; Kelsen, J.; Christensen, L.A.; Dahlerup, J.F. Clinical trial: Vitamin D3 treatment in Crohn's disease-A randomized double-blind placebo-controlled study. Aliment. Pharmacol. Ther. 2010, 32, 377-383. [CrossRef] [PubMed]

164. Gubatan, J.; Chou, N.D.; Nielsen, O.H.; Moss, A.C. Systematic review with meta-analysis: Association of vitamin D status with clinical outcomes in adult patients with inflammatory bowel disease. Aliment. Pharmacol. Ther. 2019, 50, 1146-1158. [CrossRef] [PubMed]

165. Li, J.; Chen, N.; Wang, D.; Zhang, J.; Gong, X. Efficacy of vitamin D in treatment of inflammatory bowel disease: A meta-analysis. Medicine (Baltimore) 2018, 97, e12662. [CrossRef] [PubMed]

166. Goverman, J. Autoimmune T cell responses in the central nervous system. Nat. Rev. Immunol. 2009, 9, 393-407. [CrossRef]

167. Compston, A.; Coles, A. Multiple sclerosis. Lancet 2002, 359, 1221-1231. [CrossRef]

168. Shail, M.S. Neuropsychiatry in Demyelination Disease: Using Depression as a Prodrome for Early Diagnosis and Treatment of Multiple Sclerosis. Cureus 2017, 9, e1813. [CrossRef]

169. Haider, L.; Fischer, M.T.; Frischer, J.M.; Bauer, J.; Hoftberger, R.; Botond, G.; Esterbauer, H.; Binder, C.J.; Witztum, J.L.; Lassmann, H. Oxidative damage in multiple sclerosis lesions. Brain 2011, 134, 1914-1924. [CrossRef]

170. Arnold, P.; Mojumder, D.; Detoledo, J.; Lucius, R.; Wilms, H. Pathophysiological processes in multiple sclerosis: Focus on nuclear factor erythroid-2-related factor 2 and emerging pathways. Clin. Pharmacol. 2014, 6, 35-42.

171. Fischer, M.T.; Sharma, R.; Lim, J.L.; Haider, L.; Frischer, J.M.; Drexhage, J.; Mahad, D.; Bradl, M.; van Horssen, J.; Lassmann, H. NADPH oxidase expression in active multiple sclerosis lesions in relation to oxidative tissue damage and mitochondrial injury. Brain 2012, 135, 886-899. [CrossRef] [PubMed] 
172. Su, K.; Bourdette, D.; Forte, M. Mitochondrial dysfunction and neurodegeneration in multiple sclerosis. Front. Physiol. 2013, 4 , 169. [CrossRef]

173. Volterra, A.; Trotti, D.; Tromba, C.; Floridi, S.; Racagni, G. Glutamate uptake inhibition by oxygen free radicals in rat cortical astrocytes. J. Neurosci. 1994, 14, 2924-2932. [CrossRef] [PubMed]

174. Shinpo, K.; Kikuchi, S.; Sasaki, H.; Moriwaka, F.; Tashiro, K. Effect of 1,25-dihydroxyvitamin D(3) on cultured mesencephalic dopaminergic neurons to the combined toxicity caused by L-buthionine sulfoximine and 1-methyl-4-phenylpyridine. J. Neurosci. Res. 2000, 62, 374-382. [CrossRef]

175. Berlanga-Taylor, A.J.; Disanto, G.; Ebers, G.C.; Ramagopalan, S.V. Vitamin D-gene interactions in multiple sclerosis. J. Neurol. Sci. 2011, 311, 32-36. [CrossRef] [PubMed]

176. Krizova, L.; Kollar, B.; Jezova, D.; Turcani, P. Genetic aspects of vitamin D receptor and metabolism in relation to the risk of multiple sclerosis. Gen. Physiol. Biophys. 2013, 32, 459-466. [CrossRef] [PubMed]

177. Harms, L.R.; Burne, T.H.; Eyles, D.W.; McGrath, J.J. Vitamin D and the brain. Best Pract Res. Clin. Endocrinol. Metab. 2011, 25, 657-669. [CrossRef] [PubMed]

178. Hayes, C.E. Vitamin D: A natural inhibitor of multiple sclerosis. Proc. Nutr. Soc. 2000, 59, 531-535. [CrossRef] [PubMed]

179. Ramagopalan, S.V.; Heger, A.; Berlanga, A.J.; Maugeri, N.J.; Lincoln, M.R.; Burrell, A.; Handunnetthi, L.; Handel, A.E.; Disanto, G.; Orton, S.M.; et al. A ChIP-seq defined genome-wide map of vitamin D receptor binding: Associations with disease and evolution. Genome Res. 2010, 20, 1352-1360. [CrossRef] [PubMed]

180. Smolders, J.; Peelen, E.; Thewissen, M.; Menheere, P.; Tervaert, J.W.; Hupperts, R.; Damoiseaux, J. The relevance of vitamin D receptor gene polymorphisms for vitamin D research in multiple sclerosis. Autoimmun. Rev. 2009, 8, 621-626. [CrossRef] [PubMed]

181. Behrens, J.R.; Rasche, L.; Giess, R.M.; Pfuhl, C.; Wakonig, K.; Freitag, E.; Deuschle, K.; Bellmann-Strobl, J.; Paul, F.; Ruprecht, K.; et al. Low 25 -hydroxyvitamin $\mathrm{D}$, but not the bioavailable fraction of 25 -hydroxyvitamin $\mathrm{D}$, is a risk factor for multiple sclerosis. Eur. J. Neurol. 2016, 23, 62-67. [CrossRef] [PubMed]

182. Laursen, J.H.; Sondergaard, H.B.; Sorensen, P.S.; Sellebjerg, F.; Oturai, A.B. Vitamin D supplementation reduces relapse rate in relapsing-remitting multiple sclerosis patients treated with natalizumab. Mult. Scler. Relat. Disord. 2016, 10, 169-173. [CrossRef] [PubMed]

183. Muris, A.H.; Smolders, J.; Rolf, L.; Klinkenberg, L.J.; van der Linden, N.; Meex, S.; Damoiseaux, J.; Hupperts, R. Vitamin D Status Does Not Affect Disability Progression of Patients with Multiple Sclerosis over Three Year Follow-Up. PLoS ONE 2016, 11, e0156122. [CrossRef]

184. Hammad, H.; Lambrecht, B.N. Dendritic cells and epithelial cells: Linking innate and adaptive immunity in asthma. Nat. Rev. Immunol. 2008, 8, 193-204. [CrossRef]

185. Poon, A.H.; Laprise, C.; Lemire, M.; Montpetit, A.; Sinnett, D.; Schurr, E.; Hudson, T.J. Association of vitamin D receptor genetic variants with susceptibility to asthma and atopy. Am. J. Respir. Crit. Care Med. 2004, 170, 967-973. [CrossRef]

186. Raby, B.A.; Lazarus, R.; Silverman, E.K.; Lake, S.; Lange, C.; Wjst, M.; Weiss, S.T. Association of vitamin D receptor gene polymorphisms with childhood and adult asthma. Am. J. Respir. Crit. Care Med. 2004, 170, 1057-1065. [CrossRef]

187. Vollmert, C.; Illig, T.; Altmuller, J.; Klugbauer, S.; Loesgen, S.; Dumitrescu, L.; Wjst, M. Single nucleotide polymorphism screening and association analysis-Exclusion of integrin beta 7 and vitamin D receptor (chromosome 12q) as candidate genes for asthma Clin. Exp. Allergy 2004, 34, 1841-1850. [CrossRef]

188. Urashima, M.; Segawa, T.; Okazaki, M.; Kurihara, M.; Wada, Y.; Ida, H. Randomized trial of vitamin D supplementation to prevent seasonal influenza A in schoolchildren. Am. J. Clin. Nutr. 2010, 91, 1255-1260. [CrossRef] [PubMed]

189. Hollams, E.M.; Hart, P.H.; Holt, B.J.; Serralha, M.; Parsons, F.; de Klerk, N.H.; Zhang, G.; Sly, P.D.; Holt, P.G. Vitamin D and atopy and asthma phenotypes in children: A longitudinal cohort study. Eur. Respir. J. 2011, 38, 1320-1327. [CrossRef] [PubMed]

190. Iqbal, S.F.; Freishtat, R.J. Mechanism of action of vitamin D in the asthmatic lung. J. Investig. Med. 2011, 59, 1200-1202. [CrossRef] [PubMed]

191. Mai, X.M.; Langhammer, A.; Camargo, C.A., Jr.; Chen, Y. Serum 25-hydroxyvitamin D levels and incident asthma in adults: The HUNT Study. Am. J. Epidemiol. 2012, 176, 1169-1176. [CrossRef]

192. Tolppanen, A.M.; Sayers, A.; Granell, R.; Fraser, W.D.; Henderson, J.; Lawlor, D.A. Prospective association of 25-hydroxyvitamin $\mathrm{d} 3$ and $\mathrm{d} 2$ with childhood lung function, asthma, wheezing, and flexural dermatitis. Epidemiology 2013, 24, 310-319. [CrossRef]

193. Harvey, N.C.; Holroyd, C.; Ntani, G.; Javaid, K.; Cooper, P.; Moon, R.; Cole, Z.; Tinati, T.; Godfrey, K.; Dennison, E.; et al. Vitamin D supplementation in pregnancy: A systematic review. Health Technol. Assess. 2014, 18, 1-190. [CrossRef] [PubMed]

194. Casteels, K.; Waer, M.; Bouillon, R.; Depovere, J.; Valckx, D.; Laureys, J.; Mathieu, C. 1,25-Dihydroxyvitamin D3 restores sensitivity to cyclophosphamide-induced apoptosis in non-obese diabetic (NOD) mice and protects against diabetes. Clin. Exp. Immunol. 1998, 112, 181-187. [CrossRef]

195. Littorin, B.; Blom, P.; Scholin, A.; Arnqvist, H.J.; Blohme, G.; Bolinder, J.; Ekbom-Schnell, A.; Eriksson, J.W.; Gudbjornsdottir, S.; Nystrom, L.; et al. Lower levels of plasma 25-hydroxyvitamin D among young adults at diagnosis of autoimmune type 1 diabetes compared with control subjects: Results from the nationwide Diabetes Incidence Study in Sweden (DISS). Diabetologia 2006, 49, 2847-2852. [CrossRef]

196. Svoren, B.M.; Volkening, L.K.; Wood, J.R.; Laffel, L.M. Significant vitamin D deficiency in youth with type 1 diabetes mellitus. J. Pediatrics 2009, 154, 132-134. [CrossRef] 
197. Pani, M.A.; Knapp, M.; Donner, H.; Braun, J.; Baur, M.P.; Usadel, K.H.; Badenhoop, K. Vitamin D receptor allele combinations influence genetic susceptibility to type 1 diabetes in Germans. Diabetes 2000, 49, 504-507. [CrossRef] [PubMed]

198. Chang, T.J.; Lei, H.H.; Yeh, J.I.; Chiu, K.C.; Lee, K.C.; Chen, M.C.; Tai, T.Y.; Chuang, L.M. Vitamin D receptor gene polymorphisms influence susceptibility to type 1 diabetes mellitus in the Taiwanese population. Clin. Endocrinol. 2000, 52, 575-580. [CrossRef]

199. Pociot, F.; McDermott, M.F. Genetics of type 1 diabetes mellitus. Genes Immun. 2002, 3, 235-249. [CrossRef] [PubMed]

200. Bailey, R.; Cooper, J.D.; Zeitels, L.; Smyth, D.J.; Yang, J.H.; Walker, N.M.; Hypponen, E.; Dunger, D.B.; Ramos-Lopez, E.; Badenhoop, K.; et al. Association of the vitamin D metabolism gene CYP27B1 with type 1 diabetes. Diabetes 2007, 56, 2616-2621. [CrossRef] [PubMed]

201. Mathieu, C.; Gysemans, C.; Giulietti, A.; Bouillon, R. Vitamin D and diabetes. Diabetologia 2005, 48, 1247-1257. [CrossRef] [PubMed]

202. Knip, M.; Akerblom, H.K. Early nutrition and later diabetes risk. Adv. Exp. Med. Biol. 2005, 569, 142-150.

203. Lucas, R.M.; Ponsonby, A.L.; Pasco, J.A.; Morley, R. Future health implications of prenatal and early-life vitamin D status. Nutr. Rev. 2008, 66, 710-720. [CrossRef]

204. Stene, L.C.; Ulriksen, J.; Magnus, P.; Joner, G. Use of cod liver oil during pregnancy associated with lower risk of Type I diabetes in the offspring. Diabetologia 2000, 43, 1093-1098. [CrossRef]

205. Cutolo, M.; Otsa, K. Review: Vitamin D, immunity and lupus. Lupus 2008, 17, 6-10. [CrossRef]

206. Abe, J.; Nakamura, K.; Takita, Y.; Nakano, T.; Irie, H.; Nishii, Y. Prevention of immunological disorders in MRL/1 mice by a new synthetic analogue of vitamin D3: 22-oxa-1 alpha,25-dihydroxyvitamin D3. J. Nutr. Sci. Vitaminol. 1990, 36, 21-31. [CrossRef]

207. Lemire, J.M.; Ince, A.; Takashima, M. 1,25-Dihydroxyvitamin D3 attenuates the expression of experimental murine lupus of MRL/1 mice. Autoimmunity 1992, 12, 143-148. [CrossRef]

208. Tabasi, N.; Rastin, M.; Mahmoudi, M.; Ghoryani, M.; Mirfeizi, Z.; Rabe, S.Z.; Reihani, H. Influence of vitamin D on cell cycle, apoptosis, and some apoptosis related molecules in systemic lupus erythematosus. Iran. J. Basic Med. Sci. 2015, 18, 1107-1111.

209. Kamen, D.L. Vitamin D in lupus-New kid on the block? Bull. NYU Hosp. Jt. Dis. 2010, 68, $218-222$.

210. Reynolds, J.A.; Haque, S.; Williamson, K.; Ray, D.W.; Alexander, M.Y.; Bruce, I.N. Vitamin D improves endothelial dysfunction and restores myeloid angiogenic cell function via reduced CXCL-10 expression in systemic lupus erythematosus. Sci. Rep. 2016, 6, 22341. [CrossRef] [PubMed]

211. Mao, S.; Huang, S. Association between vitamin D receptor gene BsmI, FokI, ApaI and TaqI polymorphisms and the risk of systemic lupus erythematosus: A meta-analysis. Rheumatol. Int. 2014, 34, 381-388. [CrossRef] [PubMed]

212. Carvalho, C.; Marinho, A.; Leal, B.; Bettencourt, A.; Boleixa, D.; Almeida, I.; Farinha, F.; Costa, P.P.; Vasconcelos, C.; Silva, B.M. Association between vitamin D receptor (VDR) gene polymorphisms and systemic lupus erythematosus in Portuguese patients. Lupus 2015, 24, 846-853. [CrossRef] [PubMed]

213. Costenbader, K.H.; Feskanich, D.; Holmes, M.; Karlson, E.W.; Benito-Garcia, E. Vitamin D intake and risks of systemic lupus erythematosus and rheumatoid arthritis in women. Ann. Rheum. Dis. 2008, 67, 530-535. [CrossRef]

214. Adams, J.S.; Hewison, M. Update in vitamin D. J. Clin. Endocrinol. Metab. 2010, 95, 471-478. [CrossRef]

215. Grant, W.B. The Health Benefits of Solar Irradiance and Vitamin D and the Consequences of Their Deprivation. Clin. Rev. Bone Miner. Metab. 2009, 7, 134-146. [CrossRef]

216. Bikle, D.D. Extra Renal Synthesis of 1,25-dihydroxyvitamin D and its Health Implications. Clin. Rev. Bone Miner. Metab. 2009, 7, 114-125. [CrossRef]

217. Rook, G.A.; Steele, J.; Fraher, L.; Barker, S.; Karmali, R.; O’Riordan, J.; Stanford, J. Vitamin D3, gamma interferon, and control of proliferation of Mycobacterium tuberculosis by human monocytes. Immunology 1986, 57, 159-163.

218. Liu, P.T.; Stenger, S.; Li, H.; Wenzel, L.; Tan, B.H.; Krutzik, S.R.; Ochoa, M.T.; Schauber, J.; Wu, K.; Meinken, C.; et al. Toll-like receptor triggering of a vitamin D-mediated human antimicrobial response. Science 2006, 311, 1770-1773. [CrossRef] [PubMed]

219. Crowle, A.J.; Ross, E.J.; May, M.H. Inhibition by 1,25(OH)2-vitamin D3 of the multiplication of virulent tubercle bacilli in cultured human macrophages. Infect. Immun. 1987, 55, 2945-2950. [CrossRef]

220. Amuchastegui, S.; Daniel, K.C.; Adorini, L. Inhibition of acute and chronic allograft rejection in mouse models by BXL-628, a nonhypercalcemic vitamin D receptor agonist. Transplantation 2005, 80, 81-87. [CrossRef]

221. Nursyam, E.W.; Amin, Z.; Rumende, C.M. The effect of vitamin D as supplementary treatment in patients with moderately advanced pulmonary tuberculous lesion. Acta Med. Indones 2006, 38, 3-5. [PubMed]

222. Aloia, J.F.; Li-Ng, M. Re: Epidemic influenza and vitamin D. Epidemiol. Infect. 2007, 135, author reply 1097-1098. [CrossRef]

223. Martineau, A.R.; Wilkinson, R.J.; Wilkinson, K.A.; Newton, S.M.; Kampmann, B.; Hall, B.M.; Packe, G.E.; Davidson, R.N.; Eldridge, S.M.; Maunsell, Z.J.; et al. A single dose of vitamin D enhances immunity to mycobacteria. Am. J. Respir. Crit. Care Med. 2007, 176, 208-213. [CrossRef] [PubMed]

224. Marazuela, M.; Giustina, A.; Puig-Domingo, M. Endocrine and metabolic aspects of the COVID-19 pandemic. Rev. Endocr. Metab. Disord. 2020, 21, 495-507. [CrossRef]

225. Mitchell, F. Vitamin-D and COVID-19: Do deficient risk a poorer outcome? Lancet Diabetes Endocrinol. 2020, 8, 570. [CrossRef]

226. Bilezikian, J.P.; Bikle, D.; Hewison, M.; Lazaretti-Castro, M.; Formenti, A.M.; Gupta, A.; Madhavan, M.V.; Nair, N.; Babalyan, V.; Hutchings, N.; et al. Mechanisms in endocrinology: Vitamin D and COVID-19. Eur. J. Endocrinol. 2020, 183, R133-R147. [CrossRef] [PubMed] 
227. Dickie, L.J.; Church, L.D.; Coulthard, L.R.; Mathews, R.J.; Emery, P.; McDermott, M.F. Vitamin D3 down-regulates intracellular Toll-like receptor 9 expression and Toll-like receptor 9-induced IL-6 production in human monocytes. Rheumatology (Oxford) 2010, 49, 1466-1471. [CrossRef] [PubMed]

228. Hadjadj, J.; Yatim, N.; Barnabei, L.; Corneau, A.; Boussier, J.; Smith, N.; Pere, H.; Charbit, B.; Bondet, V.; Chenevier-Gobeaux, C.; et al. Impaired type I interferon activity and inflammatory responses in severe COVID-19 patients. Science 2020, 369, 718-724. [CrossRef] [PubMed]

229. Broggi, A.; Ghosh, S.; Sposito, B.; Spreafico, R.; Balzarini, F.; Lo Cascio, A.; Clementi, N.; De Santis, M.; Mancini, N.; Granucci, F.; et al. Type III interferons disrupt the lung epithelial barrier upon viral recognition. Science 2020, 369, 706-712. [CrossRef] [PubMed]

230. Yang, J.; Jun, X.U.; Zhang, H. Effect of vitamin D on ACE2 and vitamin D receptor expression in rats with LPS-induced acute lung injury. Chin. J. Emerg. Med. 2016, 25, 1284-1289.

231. Martineau, A.R.; Jolliffe, D.A.; Hooper, R.L.; Greenberg, L.; Aloia, J.F.; Bergman, P.; Dubnov-Raz, G.; Esposito, S.; Ganmaa, D.; Ginde, A.A.; et al. Vitamin D supplementation to prevent acute respiratory tract infections: Systematic review and meta-analysis of individual participant data. BMJ 2017, 356, i6583. [CrossRef]

232. Pereira, M.; Dantas Damascena, A.; Galvao Azevedo, L.M.; de Almeida Oliveira, T.; da Mota Santana, J. Vitamin D deficiency aggravates COVID-19: Systematic review and meta-analysis. Crit Rev. Food Sci. Nutr. 2020, 1-9. [CrossRef]

233. Pinzon, R.T.; Angela; Pradana, A.W. Vitamin D deficiency among patients with COVID-19: Case series and recent literature review. Trop. Med. Health 2020, 48, 102. [CrossRef]

234. Liu, N.; Sun, J.; Wang, X.; Zhang, T.; Zhao, M.; Li, H. Low vitamin D status is associated with coronavirus disease 2019 outcomes: A systematic review and meta-analysis. Int. J. Infect. Dis. 2021, 104, 58-64. [CrossRef]

235. Shah, K.; Saxena, D.; Mavalankar, D. Vitamin D supplementation, COVID-19 \& Disease Severity: A meta-analysis. QJM 2021. [CrossRef]

236. Lim, H.S.; Roychoudhuri, R.; Peto, J.; Schwartz, G.; Baade, P.; Moller, H. Cancer survival is dependent on season of diagnosis and sunlight exposure. Int. J. Cancer 2006, 119, 1530-1536. [CrossRef]

237. Grant, W.B. Ecologic studies of solar UV-B radiation and cancer mortality rates. Recent Results Cancer Res. 2003, 164, 371-377.

238. Garland, C.F.; Garland, F.C. Do sunlight and vitamin D reduce the likelihood of colon cancer? Int. J. Epidemiol. 1980, 9, 227-231. [CrossRef] [PubMed]

239. Grant, W.B.; Mohr, S.B. Ecological studies of ultraviolet B, vitamin D and cancer since 2000. Ann. Epidemiol. 2009, 19, 446-454. [CrossRef] [PubMed]

240. Cross, H.S.; Huber, C.; Peterlik, M. Antiproliferative effect of 1,25-dihydroxyvitamin D3 and its analogs on human colon adenocarcinoma cells (CaCo-2): Influence of extracellular calcium. Biochem. Biophys Res. Commun. 1991, 179, 57-62. [CrossRef]

241. Halline, A.G.; Davidson, N.O.; Skarosi, S.F.; Sitrin, M.D.; Tietze, C.; Alpers, D.H.; Brasitus, T.A. Effects of 1,25-dihydroxyvitamin D3 on proliferation and differentiation of Caco-2 cells. Endocrinology 1994, 134, 1710-1717. [CrossRef]

242. Mokady, E.; Schwartz, B.; Shany, S.; Lamprecht, S.A. A protective role of dietary vitamin D3 in rat colon carcinogenesis. Nutr. Cancer 2000, 38, 65-73. [CrossRef]

243. Tangpricha, V.; Spina, C.; Yao, M.; Chen, T.C.; Wolfe, M.M.; Holick, M.F. Vitamin D deficiency enhances the growth of MC-26 colon cancer xenografts in Balb/c mice. J. Nutr. 2005, 135, 2350-2354. [CrossRef] [PubMed]

244. Huerta, S.; Irwin, R.W.; Heber, D.; Go, V.L.; Koeffler, H.P.; Uskokovic, M.R.; Harris, D.M. 1alpha,25-(OH)(2)-D(3) and its synthetic analogue decrease tumor load in the Apc(min) Mouse. Cancer Res. 2002, 62, 741-746.

245. Mehta, R.G. Stage-specific inhibition of mammary carcinogenesis by 1alpha-hydroxyvitamin D5. Eur. J. Cancer 2004, 40, $2331-2337$. [CrossRef] [PubMed]

246. Seubwai, W.; Wongkham, C.; Puapairoj, A.; Okada, S.; Wongkham, S. 22-oxa-1,25-dihydroxyvitamin D3 efficiently inhibits tumor growth in inoculated mice and primary histoculture of cholangiocarcinoma. Cancer 2010, 116, 5535-5543. [CrossRef] [PubMed]

247. Sitrin, M.D.; Halline, A.G.; Abrahams, C.; Brasitus, T.A. Dietary calcium and vitamin D modulate 1,2-dimethylhydrazine-induced colonic carcinogenesis in the rat. Cancer Res. 1991, 51, 5608-5613.

248. Llor, X.; Jacoby, R.F.; Teng, B.B.; Davidson, N.O.; Sitrin, M.D.; Brasitus, T.A. K-ras mutations in 1,2-dimethylhydrazine-induced colonic tumors: Effects of supplemental dietary calcium and vitamin D deficiency. Cancer Res. 1991, 51, 4305-4309. [PubMed]

249. Mordan-McCombs, S.; Brown, T.; Wang, W.L.; Gaupel, A.C.; Welsh, J.; Tenniswood, M. Tumor progression in the LPB-Tag transgenic model of prostate cancer is altered by vitamin D receptor and serum testosterone status. J. Steroid Biochem. Mol. Biol. 2010, 121, 368-371. [CrossRef] [PubMed]

250. Zinser, G.M.; Suckow, M.; Welsh, J. Vitamin D receptor (VDR) ablation alters carcinogen-induced tumorigenesis in mammary gland, epidermis and lymphoid tissues. J. Steroid Biochem. Mol. Biol. 2005, 97, 153-164. [CrossRef]

251. Zheng, W.; Wong, K.E.; Zhang, Z.; Dougherty, U.; Mustafi, R.; Kong, J.; Deb, D.K.; Zheng, H.; Bissonnette, M.; Li, Y.C. Inactivation of the vitamin D receptor in $\mathrm{APC}(\mathrm{min} /+)$ mice reveals a critical role for the vitamin D receptor in intestinal tumor growth. Int. J. Cancer 2012, 130, 10-19. [CrossRef]

252. Feldman, D.; Krishnan, A.V.; Swami, S.; Giovannucci, E.; Feldman, B.J. The role of vitamin D in reducing cancer risk and progression. Nat. Rev. Cancer 2014, 14, 342-357. [CrossRef]

253. Garland, C.F.; Comstock, G.W.; Garland, F.C.; Helsing, K.J.; Shaw, E.K.; Gorham, E.D. Serum 25-hydroxyvitamin D and colon cancer: Eight-year prospective study. Lancet 1989, 2, 1176-1178. [CrossRef] 
254. Gandini, S.; Boniol, M.; Haukka, J.; Byrnes, G.; Cox, B.; Sneyd, M.J.; Mullie, P.; Autier, P. Meta-analysis of observational studies of serum 25-hydroxyvitamin D levels and colorectal, breast and prostate cancer and colorectal adenoma. Int. J. Cancer 2011, 128, 1414-1424. [CrossRef]

255. Newberry, S.J.; Chung, M.; Shekelle, P.G.; Booth, M.S.; Liu, J.L.; Maher, A.R.; Motala, A.; Cui, M.; Perry, T.; Shanman, R.; et al. Vitamin D and Calcium: A Systematic Review of Health Outcomes (Update). Evid. Rep. Technol. Assess. (Full Rep.) 2014, 1-929. [CrossRef]

256. Neuhouser, M.L.; Manson, J.E.; Millen, A.; Pettinger, M.; Margolis, K.; Jacobs, E.T.; Shikany, J.M.; Vitolins, M.; Adams-Campbell, L.; Liu, S.; et al. The influence of health and lifestyle characteristics on the relation of serum 25-hydroxyvitamin D with risk of colorectal and breast cancer in postmenopausal women. Am. J. Epidemiol. 2012, 175, 673-684. [CrossRef]

257. Weinstein, S.J.; Purdue, M.P.; Smith-Warner, S.A.; Mondul, A.M.; Black, A.; Ahn, J.; Huang, W.Y.; Horst, R.L.; Kopp, W.; Rager, H.; et al. Serum 25-hydroxyvitamin D, vitamin D binding protein and risk of colorectal cancer in the Prostate, Lung, Colorectal and Ovarian Cancer Screening Trial. Int. J. Cancer 2015, 136, E654-E664. [CrossRef] [PubMed]

258. Engel, P.; Fagherazzi, G.; Boutten, A.; Dupre, T.; Mesrine, S.; Boutron-Ruault, M.C.; Clavel-Chapelon, F. Serum 25(OH) vitamin D and risk of breast cancer: A nested case-control study from the French E3N cohort. Cancer Epidemiol. Biomarkers Prev. 2010, 19, 2341-2350. [CrossRef]

259. Kim, Y.; Franke, A.A.; Shvetsov, Y.B.; Wilkens, L.R.; Cooney, R.V.; Lurie, G.; Maskarinec, G.; Hernandez, B.Y.; Le Marchand, L.; Henderson, B.E.; et al. Plasma 25-hydroxyvitamin D3 is associated with decreased risk of postmenopausal breast cancer in whites: A nested case-control study in the multiethnic cohort study. BMC Cancer 2014, 14, 29. [CrossRef]

260. Ahonen, M.H.; Tenkanen, L.; Teppo, L.; Hakama, M.; Tuohimaa, P. Prostate cancer risk and prediagnostic serum 25hydroxyvitamin D levels (Finland). Cancer Causes Control. 2000, 11, 847-852. [CrossRef] [PubMed]

261. Tretli, S.; Hernes, E.; Berg, J.P.; Hestvik, U.E.; Robsahm, T.E. Association between serum 25(OH)D and death from prostate cancer. Br. J. Cancer 2009, 100, 450-454. [CrossRef]

262. Giovannucci, E.; Liu, Y.; Rimm, E.B.; Hollis, B.W.; Fuchs, C.S.; Stampfer, M.J.; Willett, W.C. Prospective study of predictors of vitamin D status and cancer incidence and mortality in men. J. Natl. Cancer Inst. 2006, 98, 451-459. [CrossRef]

263. Mondul, A.M.; Weinstein, S.J.; Mannisto, S.; Snyder, K.; Horst, R.L.; Virtamo, J.; Albanes, D. Serum vitamin D and risk of bladder cancer. Cancer Res. 2010, 70, 9218-9223. [CrossRef]

264. Fedirko, V.; Duarte-Salles, T.; Bamia, C.; Trichopoulou, A.; Aleksandrova, K.; Trichopoulos, D.; Trepo, E.; Tjonneland, A.; Olsen, A.; Overvad, K.; et al. Prediagnostic circulating vitamin D levels and risk of hepatocellular carcinoma in European populations: A nested case-control study. Hepatology 2014, 60, 1222-1230. [CrossRef]

265. de Boer, I.H.; Levin, G.; Robinson-Cohen, C.; Biggs, M.L.; Hoofnagle, A.N.; Siscovick, D.S.; Kestenbaum, B. Serum 25hydroxyvitamin D concentration and risk for major clinical disease events in a community-based population of older adults: A cohort study. Ann. Intern. Med. 2012, 156, 627-634. [CrossRef]

266. Manson, J.E.; Cook, N.R.; Lee, I.M.; Christen, W.; Bassuk, S.S.; Mora, S.; Gibson, H.; Gordon, D.; Copeland, T.; D’Agostino, D.; et al. Vitamin D Supplements and Prevention of Cancer and Cardiovascular Disease. N. Engl. J. Med. 2019, 380, 33-44. [CrossRef] [PubMed]

267. Caini, S.; Boniol, M.; Tosti, G.; Magi, S.; Medri, M.; Stanganelli, I.; Palli, D.; Assedi, M.; Marmol, V.D.; Gandini, S. Vitamin D and melanoma and non-melanoma skin cancer risk and prognosis: A comprehensive review and meta-analysis. Eur. J. Cancer 2014, 50, 2649-2658. [CrossRef]

268. Stolzenberg-Solomon, R.Z.; Jacobs, E.J.; Arslan, A.A.; Qi, D.; Patel, A.V.; Helzlsouer, K.J.; Weinstein, S.J.; McCullough, M.L.; Purdue, M.P.; Shu, X.O.; et al. Circulating 25-hydroxyvitamin D and risk of pancreatic cancer: Cohort Consortium Vitamin D Pooling Project of Rarer Cancers. Am. J. Epidemiol. 2010, 172, 81-93. [CrossRef] [PubMed]

269. McCullough, M.L.; Weinstein, S.J.; Freedman, D.M.; Helzlsouer, K.; Flanders, W.D.; Koenig, K.; Kolonel, L.; Laden, F.; Le Marchand, L.; Purdue, M.; et al. Correlates of circulating 25-hydroxyvitamin D: Cohort Consortium Vitamin D Pooling Project of Rarer Cancers. Am. J. Epidemiol. 2010, 172, 21-35. [CrossRef]

270. Ordonez-Mena, J.M.; Schottker, B.; Haug, U.; Muller, H.; Kohrle, J.; Schomburg, L.; Holleczek, B.; Brenner, H. Serum 25hydroxyvitamin d and cancer risk in older adults: Results from a large German prospective cohort study. Cancer Epidemiol. Biomark. Prev. 2013, 22, 905-916. [CrossRef] [PubMed]

271. Thomas, H.; Diamond, J.; Vieco, A.; Chaudhuri, S.; Shinnar, E.; Cromer, S.; Perel, P.; Mensah, G.A.; Narula, J.; Johnson, C.O.; et al. Global Atlas of Cardiovascular Disease 2000-2016: The Path to Prevention and Control. Glob. Heart 2018, 13, 143-163. [CrossRef] [PubMed]

272. Zittermann, A.; Schleithoff, S.S.; Koerfer, R. Vitamin D and vascular calcification. Curr. Opin. Lipidol. 2007, 18, 41-46. [CrossRef]

273. Martins, D.; Wolf, M.; Pan, D.; Zadshir, A.; Tareen, N.; Thadhani, R.; Felsenfeld, A.; Levine, B.; Mehrotra, R.; Norris, K. Prevalence of cardiovascular risk factors and the serum levels of 25-hydroxyvitamin D in the United States: Data from the Third National Health and Nutrition Examination Survey. Arch. Intern. Med. 2007, 167, 1159-1165. [CrossRef]

274. Bouillon, R.; Carmeliet, G.; Verlinden, L.; van Etten, E.; Verstuyf, A.; Luderer, H.F.; Lieben, L.; Mathieu, C.; Demay, M. Vitamin D and human health: Lessons from vitamin D receptor null mice. Endocr. Rev. 2008, 29, 726-776. [CrossRef] [PubMed]

275. Toda, T.; Leszczynski, D.E.; Kummerow, F.A. The role of 25-hydroxy-vitamin D3 in the induction of atherosclerosis in swine and rabbit by hypervitaminosis D. Acta Pathol. Jpn. 1983, 33, 37-44. 
276. Toda, T.; Toda, Y.; Kummerow, F.A. Coronary arterial lesions in piglets from sows fed moderate excesses of vitamin D. Tohoku J. Exp. Med. 1985, 145, 303-310. [CrossRef] [PubMed]

277. Karakas, M.; Thorand, B.; Zierer, A.; Huth, C.; Meisinger, C.; Roden, M.; Rottbauer, W.; Peters, A.; Koenig, W.; Herder, C. Low levels of serum 25-hydroxyvitamin D are associated with increased risk of myocardial infarction, especially in women: Results from the MONICA/KORA Augsburg case-cohort study. J. Clin. Endocrinol. Metab. 2013, 98, 272-280. [CrossRef] [PubMed]

278. Robinson-Cohen, C.; Hoofnagle, A.N.; Ix, J.H.; Sachs, M.C.; Tracy, R.P.; Siscovick, D.S.; Kestenbaum, B.R.; de Boer, I.H. Racial differences in the association of serum 25-hydroxyvitamin D concentration with coronary heart disease events. JAMA 2013, 310, 179-188. [CrossRef] [PubMed]

279. Messenger, W.; Nielson, C.M.; Li, H.; Beer, T.; Barrett-Connor, E.; Stone, K.; Shannon, J. Serum and dietary vitamin D and cardiovascular disease risk in elderly men: A prospective cohort study. Nutr. Metab. Cardiovasc. Dis. 2012, 22, 856-863. [CrossRef] [PubMed]

280. Welsh, P.; Doolin, O.; McConnachie, A.; Boulton, E.; McNeil, G.; Macdonald, H.; Hardcastle, A.; Hart, C.; Upton, M.; Watt, G.; et al. Circulating 25OHD, dietary vitamin D, PTH, and calcium associations with incident cardiovascular disease and mortality: The MIDSPAN Family Study. J. Clin. Endocrinol. Metab. 2012, 97, 4578-4587. [CrossRef]

281. Lee, J.H.; O'Keefe, J.H.; Bell, D.; Hensrud, D.D.; Holick, M.F. Vitamin D deficiency an important, common, and easily treatable cardiovascular risk factor? J. Am. Coll. Cardiol. 2008, 52, 1949-1956. [CrossRef] [PubMed]

282. Wallis, D.E.; Penckofer, S.; Sizemore, G.W. The "sunshine deficit" and cardiovascular disease. Circulation 2008, 118, 1476-1485 [CrossRef]

283. Kim, H.W.; Park, C.W.; Shin, Y.S.; Kim, Y.S.; Shin, S.J.; Kim, Y.S.; Choi, E.J.; Chang, Y.S.; Bang, B.K. Calcitriol regresses cardiac hypertrophy and QT dispersion in secondary hyperparathyroidism on hemodialysis. Nephron Clin. Pract. 2006, 102, c21-c29. [CrossRef]

284. Kestenbaum, B.; Katz, R.; de Boer, I.; Hoofnagle, A.; Sarnak, M.J.; Shlipak, M.G.; Jenny, N.S.; Siscovick, D.S. Vitamin D, parathyroid hormone, and cardiovascular events among older adults. J. Am. Coll Cardiol. 2011, 58, 1433-1441. [CrossRef]

285. Anderson, J.L.; Vanwoerkom, R.C.; Horne, B.D.; Bair, T.L.; May, H.T.; Lappe, D.L.; Muhlestein, J.B. Parathyroid hormone, vitamin $\mathrm{D}$, renal dysfunction, and cardiovascular disease: Dependent or independent risk factors? Am. Heart J. 2011, 162, 331-339.e2. [CrossRef]

286. Giovannucci, E.; Liu, Y.; Hollis, B.W.; Rimm, E.B. 25-hydroxyvitamin D and risk of myocardial infarction in men: A prospective study. Arch. Intern. Med. 2008, 168, 1174-1180. [CrossRef]

287. McGreevy, C.; Williams, D. New insights about vitamin D and cardiovascular disease: A narrative review. Ann. Intern. Med. 2011, 155, 820-826. [CrossRef] [PubMed]

288. Kazlauskaite, R.; Powell, L.H.; Mandapakala, C.; Cursio, J.F.; Avery, E.F.; Calvin, J. Vitamin D is associated with atheroprotective high-density lipoprotein profile in postmenopausal women. J. Clin. Lipidol. 2010, 4, 113-119. [CrossRef] [PubMed]

289. McCann, J.C.; Ames, B.N. Is there convincing biological or behavioral evidence linking vitamin D deficiency to brain dysfunction? FASEB J. 2008, 22, 982-1001. [CrossRef]

290. Buell, J.S.; Dawson-Hughes, B. Vitamin D and neurocognitive dysfunction: Preventing “D”ecline? Mol. Aspects Med. 2008, 29, 415-422. [CrossRef] [PubMed]

291. Eyles, D.W.; Smith, S.; Kinobe, R.; Hewison, M.; McGrath, J.J. Distribution of the vitamin D receptor and 1 alpha-hydroxylase in human brain. J. Chem. Neuroanat. 2005, 29, 21-30. [CrossRef]

292. Neveu, I.; Naveilhan, P.; Jehan, F.; Baudet, C.; Wion, D.; De Luca, H.F.; Brachet, P. 1,25-dihydroxyvitamin D3 regulates the synthesis of nerve growth factor in primary cultures of glial cells. Brain Res. Mol. Brain Res. 1994, 24, 70-76. [CrossRef]

293. Naveilhan, P.; Neveu, I.; Wion, D.; Brachet, P. 1,25-Dihydroxyvitamin D3, an inducer of glial cell line-derived neurotrophic factor. Neuroreport 1996, 7, 2171-2175. [CrossRef] [PubMed]

294. Garcion, E.; Sindji, L.; Montero-Menei, C.; Andre, C.; Brachet, P.; Darcy, F. Expression of inducible nitric oxide synthase during rat brain inflammation: Regulation by 1,25-dihydroxyvitamin D3. Glia 1998, 22, 282-294. [CrossRef]

295. Sonnenberg, J.; Luine, V.N.; Krey, L.C.; Christakos, S. 1,25-Dihydroxyvitamin D3 treatment results in increased choline acetyltransferase activity in specific brain nuclei. Endocrinology 1986, 118, 1433-1439. [CrossRef]

296. Eyles, D.W.; Feron, F.; Cui, X.; Kesby, J.P.; Harms, L.H.; Ko, P.; McGrath, J.J.; Burne, T.H. Developmental vitamin D deficiency causes abnormal brain development. Psychoneuroendocrinology 2009, 34 (Suppl. 1), S247-S257. [CrossRef]

297. Smith, M.P.; Fletcher-Turner, A.; Yurek, D.M.; Cass, W.A. Calcitriol protection against dopamine loss induced by intracerebroventricular administration of 6-hydroxydopamine. Neurochem. Res. 2006, 31, 533-539. [CrossRef]

298. Wang, J.Y.; Wu, J.N.; Cherng, T.L.; Hoffer, B.J.; Chen, H.H.; Borlongan, C.V.; Wang, Y. Vitamin D(3) attenuates 6-hydroxydopamineinduced neurotoxicity in rats. Brain Res. 2001, 904, 67-75. [CrossRef]

299. van der Schaft, J.; Koek, H.L.; Dijkstra, E.; Verhaar, H.J.; van der Schouw, Y.T.; Emmelot-Vonk, M.H. The association between vitamin D and cognition: A systematic review. Ageing Res. Rev. 2013, 12, 1013-1023. [CrossRef] [PubMed]

300. Juzeniene, A.; Moan, J. Beneficial effects of UV radiation other than via vitamin D production. Dermatoendocrinol. 2012, 4, 109-117. [CrossRef] [PubMed]

301. Kim, Y.; He, Y.Y. Ultraviolet radiation-induced non-melanoma skin cancer: Regulation of DNA damage repair and inflammation. Genes Dis. 2014, 1, 188-198. [CrossRef] 
302. Pattison, D.I.; Davies, M.J. Actions of ultraviolet light on cellular structures. In Cancer: Cell Structures, Carcinogens and Genomic Instability; Bignold, L.P., Ed.; Birkhäuser: Basel, Switzerland, 2006; Volume 96, pp. 131-157. [CrossRef]

303. Cadet, J.; Douki, T.; Ravanat, J.L. Oxidatively generated damage to cellular DNA by UVB and UVA radiation. Photochem. Photobiol. 2015, 91, 140-155. [CrossRef] [PubMed]

304. Hart, P.H.; Gorman, S.; Finlay-Jones, J.J. Modulation of the immune system by UV radiation: More than just the effects of vitamin D? Nat. Rev. Immunol. 2011, 11, 584-596. [CrossRef]

305. Abhimanyu; Coussens, A.K. The role of UV radiation and vitamin D in the seasonality and outcomes of infectious disease. Photochem. Photobiol. Sci. 2017, 16, 314-338. [CrossRef]

306. Nghiem, D.X.; Kazimi, N.; Mitchell, D.L.; Vink, A.A.; Ananthaswamy, H.N.; Kripke, M.L.; Ullrich, S.E. Mechanisms underlying the suppression of established immune responses by ultraviolet radiation. J. Investig. Dermatol. 2002, 119, 600-608. [CrossRef]

307. Byrne, E.H.; Fisher, D.E. Immune and molecular correlates in melanoma treated with immune checkpoint blockade. Cancer 2017, 123, 2143-2153. [CrossRef] [PubMed]

308. Fisher, G.J.; Kang, S.; Varani, J.; Bata-Csorgo, Z.; Wan, Y.; Datta, S.; Voorhees, J.J. Mechanisms of photoaging and chronological skin aging. Arch. Dermatol. 2002, 138, 1462-1470. [CrossRef]

309. Sequeira, V.B.; Rybchyn, M.S.; Gordon-Thomson, C.; Tongkao-On, W.; Mizwicki, M.T.; Norman, A.W.; Reeve, V.E.; Halliday, G.M.; Mason, R.S. Opening of chloride channels by 1alpha,25-dihydroxyvitamin D3 contributes to photoprotection against UVR-induced thymine dimers in keratinocytes. J. Investig. Dermatol. 2013, 133, 776-782. [CrossRef] [PubMed]

310. Song, E.J.; Gordon-Thomson, C.; Cole, L.; Stern, H.; Halliday, G.M.; Damian, D.L.; Reeve, V.E.; Mason, R.S. 1alpha,25Dihydroxyvitamin D3 reduces several types of UV-induced DNA damage and contributes to photoprotection. J. Steroid Biochem. Mol. Biol. 2013, 136, 131-138. [CrossRef]

311. Damian, D.L.; Kim, Y.J.; Dixon, K.M.; Halliday, G.M.; Javeri, A.; Mason, R.S. Topical calcitriol protects from UV-induced genetic damage but suppresses cutaneous immunity in humans. Exp. Dermatol. 2010, 19, e23-e30. [CrossRef]

312. Gupta, R.; Dixon, K.M.; Deo, S.S.; Holliday, C.J.; Slater, M.; Halliday, G.M.; Reeve, V.E.; Mason, R.S. Photoprotection by 1,25 dihydroxyvitamin D3 is associated with an increase in p53 and a decrease in nitric oxide products. J. Investig. Dermatol. 2007, 127, 707-715. [CrossRef] [PubMed]

313. Bahar-Shany, K.; Ravid, A.; Koren, R. Upregulation of MMP-9 production by TNFalpha in keratinocytes and its attenuation by vitamin D. J. Cell. Physiol. 2010, 222, 729-737.

314. Cranney, A.; Horsley, T.; O’Donnell, S.; Weiler, H.; Puil, L.; Ooi, D.; Atkinson, S.; Ward, L.; Moher, D.; Hanley, D.; et al. Effectiveness and safety of vitamin D in relation to bone health. Evid. Rep. Technol. Assess. (Full Rep.) 2007, 158, 1-235.

315. Hathcock, J.N.; Shao, A.; Vieth, R.; Heaney, R. Risk assessment for vitamin D. Am. J. Clin. Nutr. 2007, 85, 6-18. [CrossRef]

316. Jones, G. Pharmacokinetics of vitamin D toxicity. Am. J. Clin. Nutr. 2008, 88, 582S-586S. [CrossRef]

317. Wacker, M.; Holick, M.F. Sunlight and Vitamin D: A global perspective for health. Dermato-Endocrinol. 2013, 5, 51-108. [CrossRef] [PubMed]

318. Araki, T.; Holick, M.F.; Alfonso, B.D.; Charlap, E.; Romero, C.M.; Rizk, D.; Newman, L.G. Vitamin D intoxication with severe hypercalcemia due to manufacturing and labeling errors of two dietary supplements made in the United States. J. Clin. Endocrinol. Metab. 2011, 96, 3603-3608. [CrossRef] [PubMed]

319. Koutkia, P.; Chen, T.C.; Holick, M.F. Vitamin D intoxication associated with an over-the-counter supplement. N. Engl. J. Med. 2001, 345, 66-67. [CrossRef] [PubMed]

320. Jacobus, C.H.; Holick, M.F.; Shao, Q.; Chen, T.C.; Holm, I.A.; Kolodny, J.M.; Fuleihan, G.E.; Seely, E.W. Hypervitaminosis D associated with drinking milk. N. Engl. J. Med. 1992, 326, 1173-1177. [CrossRef]

321. Blank, S.; Scanlon, K.S.; Sinks, T.H.; Lett, S.; Falk, H. An outbreak of hypervitaminosis D associated with the overfortification of milk from a home-delivery dairy. Am. J. Public Health 1995, 85, 656-659. [CrossRef] [PubMed]

322. Spedding, S. Vitamin D and depression: A systematic review and meta-analysis comparing studies with and without biological flaws. Nutrients 2014, 6, 1501-1518. [CrossRef] [PubMed] 